\title{
Two years of near real-time chemical composition of submicron aerosols in the region of Paris using an Aerosol Chemical Speciation Monitor (ACSM) and a multi-wavelength Aethalometer
}

\author{
J.-E. Petit ${ }^{1,2,{ }^{*} \text {, O. Favez }}{ }^{1}$, J. Sciare ${ }^{2}$, V. Crenn ${ }^{2}$, R. Sarda-Estève ${ }^{2}$, N. Bonnaire ${ }^{2}$, G. Močnik ${ }^{3}$, J.-C. Dupont ${ }^{4}$, \\ M. Haeffelin ${ }^{4}$, and E. Leoz-Garziandia ${ }^{1}$ \\ ${ }^{1}$ Institut National de l'Environnement Industriel et des Risques, Verneuil-en-Halatte, France \\ ${ }^{2}$ Laboratoire des Sciences du Climat et de l'Environnement (CNRS-CEA-UVSQ), \\ CEA Orme des Merisiers, Gif-sur-Yvette, France \\ ${ }^{3}$ Aerosol d.o.o., Ljubljana, Slovenia \\ ${ }^{4}$ Laboratoire de Météorologie Dynamique, Institut Pierre Simon Laplace, Ecole Polytechnique, Palaiseau, France \\ *now at: Air Lorraine, 20 rue Pierre Simon Laplace 57000 Metz, France
}

Correspondence to: J.-E. Petit (je.petit@air-lorraine.org)

Received: 22 July 2014 - Published in Atmos. Chem. Phys. Discuss.: 18 September 2014

Revised: 19 February 2015 - Accepted: 25 February 2015 - Published: 17 March 2015

\begin{abstract}
Aerosol mass spectrometer (AMS) measurements have been successfully used towards a better understanding of non-refractory submicron $\left(\mathrm{PM}_{1}\right)$ aerosol chemical properties based on short-term campaigns. The recently developed Aerosol Chemical Speciation Monitor (ACSM) has been designed to deliver quite similar artifact-free chemical information but for low cost, and to perform robust monitoring over long-term periods. When deployed in parallel with real-time black carbon $(\mathrm{BC})$ measurements, the combined data set allows for a quasi-comprehensive description of the whole $\mathrm{PM}_{1}$ fraction in near real time. Here we present 2year long ACSM and BC data sets, between mid-2011 and mid-2013, obtained at the French atmospheric SIRTA supersite that is representative of background PM levels of the region of Paris. This large data set shows intense and time-limited (a few hours) pollution events observed during wintertime in the region of Paris, pointing to local carbonaceous emissions (mainly combustion sources). A nonparametric wind regression analysis was performed on this 2-year data set for the major $\mathrm{PM}_{1}$ constituents (organic matter, nitrate, sulfate and source apportioned BC) and ammonia in order to better refine their geographical origins and assess local/regional/advected contributions whose information is mandatory for efficient mitigation strategies. While ammonium sulfate typically shows a clear advected pattern,
\end{abstract}

ammonium nitrate partially displays a similar feature, but, less expectedly, it also exhibits a significant contribution of regional and local emissions. The contribution of regional background organic aerosols (OA) is significant in spring and summer, while a more pronounced local origin is evidenced during wintertime, whose pattern is also observed for $\mathrm{BC}$ originating from domestic wood burning. Using timeresolved ACSM and BC information, seasonally differentiated weekly diurnal profiles of these constituents were investigated and helped to identify the main parameters controlling their temporal variations (sources, meteorological parameters). Finally, a careful investigation of all the major pollution episodes observed over the region of Paris between 2011 and 2013 was performed and classified in terms of chemical composition and the BC-to-sulfate ratio used here as a proxy of the local/regional/advected contribution of PM. In conclusion, these first 2-year quality-controlled measurements of ACSM clearly demonstrate their great potential to monitor on a long-term basis aerosol sources and their geographical origin and provide strategic information in near real time during pollution episodes. They also support the capacity of the ACSM to be proposed as a robust and credible alternative to filter-based sampling techniques for long-term monitoring strategies. 


\section{Introduction}

The understanding of the formation and fate of atmospheric particulate pollution in urban areas represents sanitary, scientific, economic, societal and political challenges, greatly amplified by increasing media coverage of pollution episodes all around the world. Growing evidence of adverse health effects of atmospheric pollutants (Chow et al., 2006; Pope and Dockery, 2006; Ramgolam et al., 2009) is illustrated by the fact that ambient air pollution has been characterized as carcinogenic since December 2013 by the International Agency for Research on Cancer (IARC, 2013). However, the "aerosol cocktail effect", directly linked to the complexity of the chemical composition and sources of the particulate phase, remains poorly understood.

In an effort to fill these lacks of knowledge, worldwide coordinated networking activities (such as Global Atmosphere Watch, European Monitoring and Evaluation Programme, and AErosol RObotic NETwork) have been documenting, for decades, the chemical, physical and optical properties of aerosol pollution in various environments. At a European level, this effort is also supported by the Aerosols, Clouds and Traces gases Research InfraStructure network (ACTRIS) program that aims at pooling high-quality data from state-ofthe-art instrumentation such as the Aerosol Chemical Speciation Monitor (ACSM, Aerodyne Research Inc., Billerica, MA, USA).

The ACSM has recently been developed with the aim of robust and easy-to-use near real-time and artifact-free measurements of the major chemical composition of nonrefractory submicron aerosol (organic matter $(\mathrm{OM}), \mathrm{NO}_{3}^{-}$, $\mathrm{SO}_{4}^{2-}, \mathrm{NH}_{4}^{+}$and $\mathrm{Cl}^{-}$) on a long-term basis ( $\mathrm{Ng}$ et al., 2011). In parallel, a growing interest is also dedicated worldwide to the monitoring of black carbon (BC), considered as an adequate indicator of potential anthropogenic emissions having sanitary impacts (Janssen et al., 2011). In particular, the use of a seven-wavelength Aethalometer (Magee Scientific, USA) allows furthermore for BC source apportionment (Sandradewi et al., 2008), proven as robust over long-term periods (Herich et al., 2011). The combination of measurements from both instruments may thus constitute an efficient and relatively low-cost tool for the monitoring of submicron aerosol chemistry and a better knowledge of their phenomenology. Such a strategy may be particularly useful for documenting aerosol sources and their geographical origin large urban areas that are characterized by a complex mixture of gaseous and particulate pollutions. Paris (France) is one of the largest European megacities and is rather isolated from other major urban environments. With $\sim 11$ million inhabitants, the Paris region accounts for $20 \%$ of the total French population distributed over only $2 \%$ of its territory, leading to enhanced exposure to various types of pollution. Moreover, the flat orography of the Paris region favors pollution transport, making it representative of northwestern European aerosol pollution. Airparif, the regional air quality monitoring net- work, recently estimated that, since 2007, about 2 million people per year have been exposed to poor air quality (referring to the daily $\mathrm{PM}_{10}$ concentration for European limit values; AIRPARIF, 2014) in this region. Over the past 7 years, annual $\mathrm{PM}_{2.5}$ concentrations in Paris have remained quite stable, although no continuous monitoring of the chemical composition of the particulate phase is available to investigate any trends in the major sources of fine aerosols.

A recent research program, based on a 1-year (2009-2010) daily filter sampling carried out at five various sites (traffic, urban, suburban and regional backgrounds; Ghersi et al., 2010), was a unique opportunity to give insight into the seasonal variations, sources and geographical origins of aerosol pollution in the region of Paris (Bressi et al., 2013, 2014; Petetin et al., 2014). However, long-term monitoring strategies based on the chemical analysis of aerosols sampled on filters are subject to various sampling and analytical artifacts (Appel et al., 1984; Turpin et al., 1994; Pathak et al., 2004; Cheng et al., 2009) and assumptions (an OC-to-OM ratio, for instance): they involve laborious laboratory analyses, they cannot capture processes governing diurnal variations of atmospheric pollutants, and fail to provide rapid diagnostics during pollution events.

In this context, Aerosol Mass Spectrometer (AMS) techniques have provided extremely valuable information on the artifact-free real-time chemical composition of submicron aerosols in urban areas over the past 10 years (Zhang et al., 2004, 2007; Jimenez et al., 2009). In Europe, OM and ammonium nitrate are generally the two main constituents of $\mathrm{PM}_{1}$ (Zhang et al., 2007), showing, however, significant discrepancies during pollution episodes in terms of chemical composition. Real-time AMS data have improved the understanding of the physical and chemical (trans)formation pathways of both fractions, through the characterization of pollution dynamics and source apportionment analyses. Intensive field campaigns involving AMS measurements were performed during the 2009 summer and 2010 winter seasons in the framework of the European MEGAPOLI (Megacities: Emissions, urban, regional and Global Atmospheric POLlution and climate effects, and Integrated tools for assessment and mitigation) research program. They greatly improved the understanding of the sources and transformation processes of Paris aerosols, and especially their submicron organic fraction (Crippa et al., 2013a, b and c; Freutel et al., 2013; Healy et al., 2012, 2013; Laborde et al., 2013; Zhang et al., 2013). However, AMS techniques' cost, size and intensive control requirements make them impractical for unattended monitoring. Nevertheless, they may still represent the best strategy for investigating specific trends in aerosol sources, especially in the context of elevated and stable PM concentrations as observed over the region of Paris during the past few years. From that perspective, the recently commercialized ACSM may represent an interesting alternative and may ultimately represent the best strategy to deploy for long-term monitoring of submicron aerosol sources and geographical origins. 
As part of the ACTRIS project, a new in situ atmospheric station was implemented in 2011 at a background site of the region of Paris, allowing the chemical, physical and optical characterization of submicron aerosol pollution on a regional scale. The key aim of the present paper is to describe and discuss one of the first long-term data sets obtained with the ACSM, offering opportunities for the evaluation of the scientific relevance of a new experimental strategy for long-term monitoring of near real-time chemical composition of $\mathrm{PM}_{1}$. Seasonal trends, wind sector analysis, diurnal variations and pollution episodes retrieved from 2-year real-time measurement ACSM and BC data sets are presented and interpreted in order to refine the origins and parameters controlling the (trans)formation of particulate pollution over the region of Paris.

\section{Material and methods}

\subsection{Sampling site and instrumentation}

Long-term in situ observations of the chemical, optical and physical properties of atmospheric aerosols have been initiated at SIRTA (Site Instrumental de Recherche par Télédétection Atmosphérique, http://sirta.ipsl.fr) since June 2011 within the EU-FP7 ACTRIS (Aerosols, Clouds, and Traces gases Research InfraStructure Network, http://www.actris. net) program. Located $20 \mathrm{~km}$ southwest of Paris $\left(2.15^{\circ} \mathrm{E}\right.$, $48.71^{\circ} \mathrm{N}, 150 \mathrm{~m}$ above sea level) in a semi-rural area, this atmospheric supersite is representative of the regional background pollution over the region of Paris (Haeffelin et al., 2005; Crippa et al., 2013a).

The chemical composition of non-refractory submicron aerosol has been continuously monitored using a Quadripole Aerosol Chemical Speciation Monitor (Aerodyne Research Inc.), which has been described in detail by $\mathrm{Ng}$ et al. (2011). Briefly, $\mathrm{PM}_{2.5}$ aerosols are sampled at $3 \mathrm{~L} \mathrm{~min}^{-1}$ (from a $\mathrm{PM}_{2.5}$ cyclone inlet) and then sub-sampled at $85 \mathrm{~mL} \mathrm{~min}^{-1}$ (volumetric flow) through an aerodynamic lens, focusing submicron particles (40-1000 $\mathrm{nm}$ aerodynamic diameter, A.D.) onto a $600{ }^{\circ} \mathrm{C}$-heated conical tungsten vaporizer where non-refractory material is flash-vaporized and quasiinstantaneously ionized by electron impact at $70 \mathrm{eV}$. Fragments are detected following their mass-to-charge ratio by a quadrupole mass spectrometer. Briefly, the instrument calibration has been performed following the recommendation of Jayne et al. (2000) and $\mathrm{Ng}$ et al. (2011), where generated mono-disperse $300 \mathrm{~nm}$ A.D. ammonium nitrate particles are injected into both ACSM and a condensation particle counter (CPC) at different concentrations. Throughout the measuring period, three response factor (RF) calibrations and one $\left(\mathrm{NH}_{4}\right)_{2} \mathrm{SO}_{4}$ calibration were performed, summarized in Table 1. The low drift of the obtained slopes allowed the use of an average response factor of $2.72 \times 10^{-11}$ (with a standard deviation of $\pm 13 \%$ ), and relative ion efficiencies (RIE) of 5.9, 1.2 and 1.4 for ammonium, sulfate and organic matter,
Table 1. Response factors obtained through IE calibrations from June 2011 to May 2013.

\begin{tabular}{lrrr}
\hline Date & Response factor & $\mathrm{RIE}_{\mathrm{NH}_{4}}$ & $\mathrm{RIE}_{\mathrm{SO}_{4}}$ \\
\hline $16 / 11 / 2011$ & $2.31 \times 10^{-11}$ & 6 & - \\
$09 / 10 / 2012$ & $2.98 \times 10^{-11}$ & 4.8 & - \\
$15 / 05 / 2013$ & $2.84 \times 10^{-11}$ & 6.84 & 1.25 \\
\hline Average & $2.72 \times 10^{-11}$ & 5.88 & - \\
Standard deviation & $13 \%$ & $17 \%$ & - \\
\hline
\end{tabular}

respectively, were used for the whole data set. Collection efficiencies were corrected using algorithms proposed by Middlebrook et al. (2012), and data were finally cross-validated using collocated $\mathrm{PM}_{1}$ as well as $\mathrm{PM}_{2.5}$ urban background measurements, retrieved from the regional association of air quality monitoring (AIRPARIF, http://www.airparif.asso.fr). The $\mathrm{PM}_{1}$ and $\mathrm{PM}_{2.5}$ data sets were obtained using tapered element oscillating microbalances (TEOM) equipped filter dynamic measurement systems (FDMS) as described by Grover (2005). A comprehensive determination of the overall uncertainty (as well as $\mathrm{PM}_{1}$ components) associated with ACSM-derived measurements was carried out in November 2013 through an inter-comparison exercise (Crenn et al., submitted; Fröhlich et al., 2015). Here, the consistency of ACSM measurements has been assessed from the comparison with co-located measurements, as described in Sect. 3.

A total number of $\sim 26000$ ACSM data points (with a temporal resolution of $30 \mathrm{~min}$ ) were collected from June 2011 to June 2013 covering on average $92 \pm 9 \%$ of each month over this 2-year period (it is to be noted that September-October 2012 and February-March 2013 were not taken into account within the latter calculation because the instrument was used for short-term intensive campaigns at other locations).

Aerosol light absorption coefficients $b_{\text {abs }}$ were retrieved every $5 \mathrm{~min}$ from a seven-wavelength $(370,470,520,590$, 660, 880 and $950 \mathrm{~nm}$ ) AE31 Aethalometer from June 2011 to February 2013, and from a seven-wavelength (370, 470, 520, 590, 660, 880 and $950 \mathrm{~nm}$ ) AE33 Aethalometer from February 2013 to May 2013. In both cases, instruments sampled aerosols with a $\mathrm{PM}_{2.5}$ cut-off inlet, operating at $5 \mathrm{~L} \mathrm{~min}^{-1}$. Filter-based absorption measurements need to be compensated for by multiple scattering in the filter matrix and for loading effects, using mathematical algorithms (Collaud Coen et al., 2010). While AE31 data were compensated for using the corrections of Weingartner et al. (2003) as described in Sciare et al. (2011), the use of the Dual-Spot Technology ${ }^{\circledR}$ in the AE33 avoids the need for manual postprocessing to compensate the data (Drinovec et al., 2014). Both instruments performed absorption measurements simultaneously during 7 days in February 2013 (Fig. S1a in the Supplement). Absorption coefficients at $880 \mathrm{~nm}$ showed a slope of 0.93 and a very satisfactory $r^{2}(0.96, n=3023$ 
of 5 min data points). Black carbon concentrations for the whole (2-year) data set were then calculated from the absorption coefficient at $880 \mathrm{~nm}$, with a mass absorption cross section (MAC) of $8.8 \mathrm{~m}^{2} \mathrm{~g}^{-1}$ (Fig. S1b), determined from the comparison with collocated filter measurements of elemental carbon (EUSAAR2 thermo-optical protocol, Cavalli et al., 2010). This value is close to the default input value implemented in the AE33 at $880 \mathrm{~nm}\left(7.77 \mathrm{~m}^{2} \mathrm{~g}^{-1}\right)$. Although still under discussion (Bond and Bergstrom, 2006; Cappa et al., 2012), such relatively high MAC values might be related to a possible encapsulation of soot particles by organic/inorganic compounds at our regional background site, and to the presence of $\mathrm{BC}$ from wood-burning emissions during wintertime, both leading to an increase in $\mathrm{BC}$ mass absorption efficiency (Liousse et al., 1993; Bond and Bergstrom, 2006; Lack et al., 2008). A total number of $\sim 280000 \mathrm{BC}$ data points $(\sim 1330005 \mathrm{~min}$ points from AE31 and $\sim 147000$ 1 min points from AE33) were collected from June 2011 to June 2013.

Ammonia measurements during selected periods (mainly during the spring, winter and summer seasons) were carried out using an AiRRmonia (Mechatronics Instruments BV, the Netherlands). Based on the conductimetric detection of ammonium, gaseous ammonia is sampled at $1 \mathrm{~L} \mathrm{~min}^{-1}$ through a sampling block equipped with an ammonia-permeable membrane; a water counter-flow allows ammonia to solubilize in ammonium. A second purification step is applied by adding $0.5 \mathrm{mM}$ sodium hydroxide, leading to the detection of ammonium in the detector block. The instrument has been calibrated regularly using solutions of 0 and $500 \mathrm{ppb}$ of ammonium. Two sets of sampling syringes ensure a constant flow throughout the instrument, but also create a temporal shift, estimated at 20 to 40 min by different studies (Cowen et al., 2004; Zechmeister-Boltenstern, 2010). In our case, this shift was set at $30 \mathrm{~min}$.

Pre-fired $47 \mathrm{~mm}$ diameter quartz filters were sampled in $\mathrm{PM}_{2.5}$ at the same location using a low-volume $\left(1 \mathrm{~m}^{3} \mathrm{~h}^{-1}\right)$ sampler (Partisol Plus, Thermo Environment) equipped with a volatile organic compound active charcoal denuder. Fourhour filters and $24 \mathrm{~h}$ filters were discontinuously sampled, respectively, from 10 February to 2 March 2012 and during the period from August 2012 to April 2013. These filters were analyzed for their water-soluble inorganic (anions and cations) and elemental/organic carbon contents using, respectively, an ion chromatography and Sunset OC / EC analyzer (EUSAAR2 thermal protocol), according to Sciare et al. (2008) and Cavalli et al. (2010).

Finally, standard meteorological parameters (temperature, relative humidity, wind speed and direction) were obtained from continuous measurements at Ecole Polytechnique, located $4 \mathrm{~km}$ east of our station, with an A100R Campbell Scientific cup anemometer for wind speed and a W200P weather vane for wind direction, at $10 \mathrm{~m}$ above ground level (m a.g.l.). Additionally, the boundary layer height (BLH) was derived from Pal et al. (2013) methodology. The attribution of the
BLH was processed in combining a diagnostic of the surface stability from high-frequency sonic anemometer measurements and LIght Detection and Ranging (LIDAR) attenuated backscatter gradients from aerosols and clouds.

All measurements presented here are expressed in Coordinated Universal Time (UTC). Seasons are differentiated upon seasonal equinoxes.

\subsection{Urban background $\mathbf{P M}_{2.5}$ measurements}

Within the framework of mandatory air quality monitoring, urban background measurements are continuously being carried out in the region of Paris. Hourly $\mathrm{PM}_{2.5}$ data from TEOM-FDMS measurements were retrieved from the three stations representative of the Paris urban background (namely, Bobigny, Gennevilliers and Vitry-sur-Seine). Data sets are available online upon request at http://www.airparif. asso.fr.

\subsection{Backtrajectories and non-parametric wind regression}

To illustrate air mass origin during specific pollution episodes, $72 \mathrm{~h}$ backtrajectories were calculated every $3 \mathrm{~h}$ from the PC-based version of Hysplit (Draxler, 1999) with GDAS meteorological field data. Backtrajectories were set to end at SIRTA coordinates $\left(48.71^{\circ} \mathrm{N}, 2.21^{\circ} \mathrm{E}\right)$ at $100 \mathrm{~m}$ a.g.l.

Non-parametric wind regression (NWR) is a smoothing algorithm (Henry et al., 2009) to alternatively display pollution roses, and has already been successfully applied to various atmospheric pollutants and pollution sources (Yu et al., 2004; Pancras et al., 2011; Olson et al., 2012). The objective is to estimate the concentration of a pollutant given any $(\theta, v)$ couple (wind direction and speed, respectively), from measured wind speed and direction, and concentration.

$$
E(\theta \mid \vartheta)=\frac{\sum_{i=1}^{N} K_{1}\left(\frac{\theta-W_{i}}{\sigma}\right) \cdot K_{2}\left(\frac{\vartheta-Y_{i}}{h}\right) \cdot C_{i}}{\sum_{i=1}^{N} K_{1}\left(\frac{\theta-W_{i}}{\sigma}\right) \cdot K_{2}\left(\frac{\vartheta-Y_{i}}{h}\right)},
$$

where $E$ is the concentration estimate at a wind direction $\theta$ and speed $v ; \mathrm{W}_{i}, \Upsilon_{i}$ and $C_{i}$ the wind direction, speed and atmospheric concentrations, respectively, measured at $t_{i} ; \sigma$ and $h$ the smoothing factors; and $K_{1}$ and $K_{2}$ two kernel smoothing functions defined as

$$
\begin{aligned}
& K_{1}(x)=\frac{1}{\sqrt{2 \pi}} \cdot e^{-0.5 \cdot x^{2}},-\infty<x<\infty . \\
& K_{2}(x)=0.75 \cdot\left(1-x^{2}\right),-1<x<1=0 .
\end{aligned}
$$

The choice of the two smoothing factors $\sigma$ and $h$ can be carried out using statistical calculations, although its empirical determination stays feasible, as the final interpretation should not be changed. Here, $\sigma$ and $h$ were set to 7 and 1.5 , similarly 


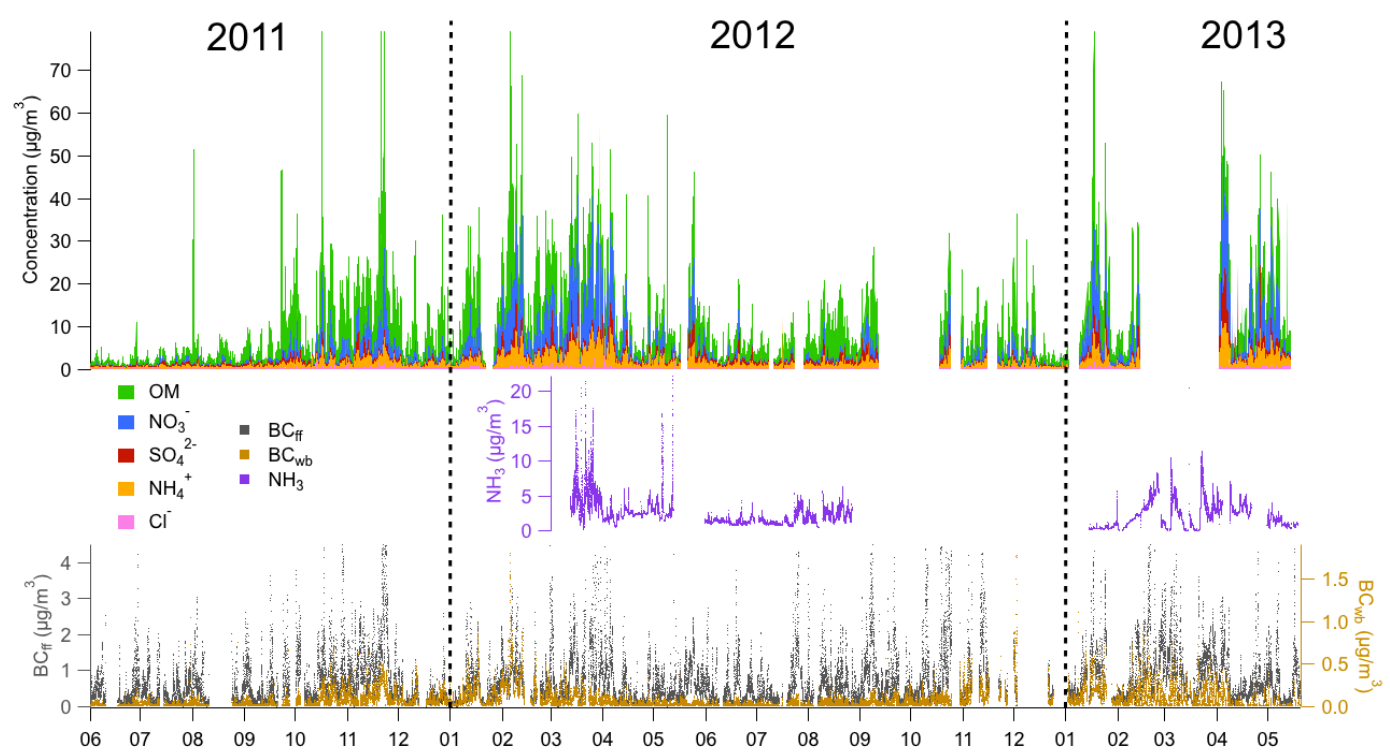

Figure 1. Time series of the major $30 \mathrm{~min}$ non-refractory (top, concentrations are aggregated) and 5 min refractory (bottom, concentrations are dissociated) $\mathrm{PM}_{1}$ chemical constituents, and 5 min ammonia at SIRTA from June 2011 to May 2013. The two large data gaps in October 2012 and March 2013 correspond to two field intensive campaigns during which the ACSM was deployed elsewhere.

to Petit et al. (2014). Finally, the equivalent of the wind rose is calculated from the probability density

$f(\theta, \vartheta)=\frac{1}{N \sigma h} \cdot \sum_{i=1}^{N} K_{1}\left(\frac{\theta-W_{i}}{\sigma}\right) K_{2}\left(\frac{\vartheta-Y_{i}}{h}\right)$

where $N$ the is the total number of points.

Due to higher measurement uncertainties in wind direction at low speeds, data associated with wind speeds lower than $1 \mathrm{~m} \mathrm{~s}^{-1}$ were discarded, potentially inducing an underestimation of very local pollution events.

\subsection{Source apportionment of carbonaceous aerosols}

The measurement of aerosol absorption at multiple wavelengths is allowing for BC source apportionment. Organic molecules, especially polycyclic aromatic hydrocarbons and humic-like substances, strongly absorb in the UV and blue parts of the light spectrum. Based on the fact that these compounds are primarily related to biomass combustion, the deconvolution of $\mathrm{BC}$ into two contributions, fuel fossil and wood burning $\left(\mathrm{BC}_{\mathrm{ff}}\right.$ and $\mathrm{BC}_{\mathrm{wb}}$, respectively), can be carried out (Sandradewi et al., 2008). Such source apportionment has already been successfully performed during intensive field campaigns as well as for long-term monitoring periods, frequently enlightening the significant contribution of wood burning to ambient $\mathrm{BC}$ concentrations during wintertime (Favez et al., 2009, 2010; Sciare et al., 2011, Herich et al., 2011; Crippa et al. 2013a). Here, the 470 and $880 \mathrm{~nm}$ channels were used, with an absorption Ångström exponent of 2.1 and 1.0 for pure wood burning and traffic, respectively, similarly to previous work focusing on the February-March 2012 period of the same data set (Petit et al., 2014).

The source apportionment of our organic aerosol data is not presented here, although positive matrix factorization applied to the AMS or ACSM database is an efficient tool for the identification of organic aerosol primary sources and secondary formation processes (see, for instance, Lanz et al., 2007; Jimenez et al., 2009; El Haddad et al., 2013; Carbone et al., 2013; Bougiatioti et al., 2014; Petit et al. 2014). Such a work will be reported elsewhere (Crenn et al., submitted), as important issues related to the seasonal variation of specific organic aerosol factor profiles have to be addressed in many details, with a lot of sensitivity tests that are beyond the objectives of the present study.

\section{Cross-validation of particulate chemical species concentrations}

Figure 1 illustrates the temporal variations of chemical species concentrations used for the present study from June 2011 to May 2013. This extended duration highlights the robustness of used instruments, and in particular the ACSM, which did not undergo any major failures over this 2-year period. The consistency of the concentrations of each chemical constituent retrieved from the ACSM has been checked via comparisons with filter measurements (Fig. 2) as well as a chemical mass closure of $\mathrm{PM}_{1}$ (Fig. 3).

ACSM nitrate is very consistent with filter measurements, the slope of the linear regression being close to $1\left(r^{2}=0.85\right.$, $N=147$ ). No overestimation of ACSM nitrate is observed at high concentrations, which suggests the ability of the Middlebrook algorithm to properly correct our ACSM collec- 

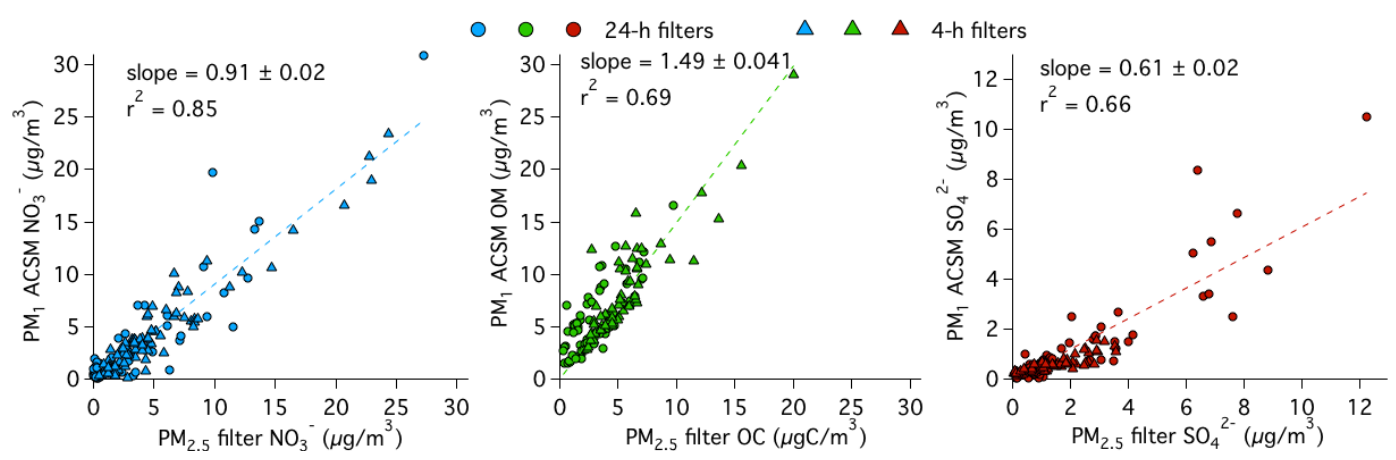

Figure 2. Scatterplot of chemically speciated ACSM measurements versus filter analyses for nitrate, organic matter (compared to OC filterbased measurements) and sulfate.

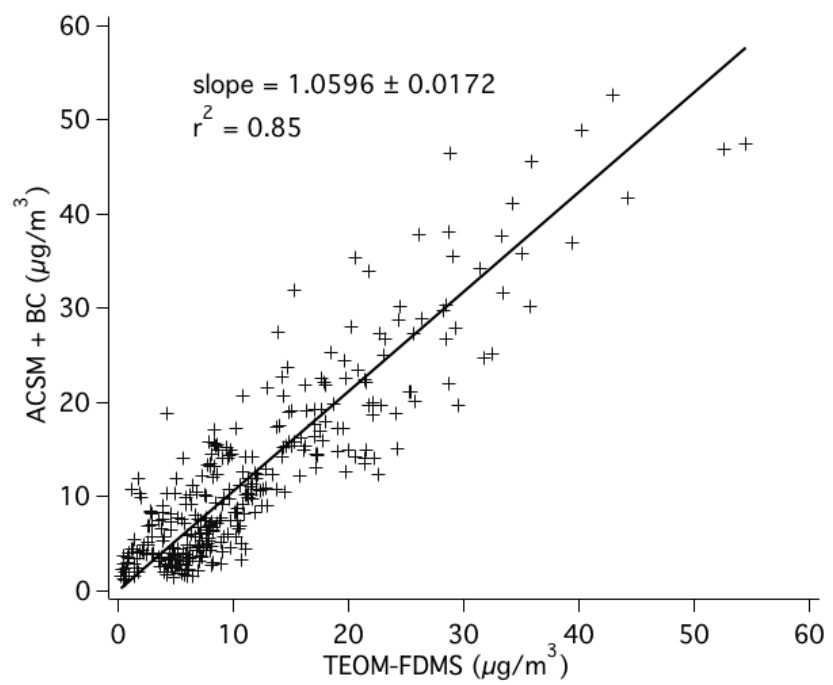

Figure 3. Mass closure exercise between daily averaged reconstructed $\mathrm{PM}_{1}(\mathrm{ACSM}+\mathrm{BC})$ and measured $\mathrm{PM}_{1}$ by TEOM-FDMS.

tion efficiencies. Higher discrepancies are observed for sulfate. This feature has already been mentioned in previous studies for ACSM (Ng et al., 2011; Budisulistiorini et al., 2014) and AMS instruments (Takegawa et al., 2005). This could be partly related to the size distribution of sulfate, as fine $\left(\mathrm{PM}_{2.5}\right)$ sulfate can partially be associated with submicron sea salt and/or dust particles. Fine ammonium sulfate aerosols originating from secondary processes and longrange transport (Sciare et al., 2010; Freutel et al., 2013) may also present a larger size mode extending above $1 \mu \mathrm{m}$ and partially not sampled by the ACSM. A sulfate ion efficiency calibration was also performed in May 2013 to investigate possible changes in RIE, but no significant discrepancy from the default value of 1.2 was found.

The OM-to-OC ratio obtained from the comparison between ACSM and filter-based measurements exhibits a mean value of approximately 1.5 , which is lower than the value recommended for urban areas (1.6 \pm 0.2 , Turpin and Lim, 2001) and $33 \%$ lower than and/or equal to values used in the Paris metropolitan area in previous studies $(\sim 2$ in Bressi et al., $2013 ; 1.6$ in Sciare et al., 2010). Although this ratio is subject to caution, by virtue of potential geographical and temporal discrepancies, the relatively low value observed here might be explained by the presence of organic material between 1 and $2.5 \mu \mathrm{m}$ as well as filter sampling artifacts.

A chemical mass closure exercise, where the combination of validated ACSM and Aethalometer data is compared to co-located $\mathrm{PM}_{1}$ TEOM-FDMS measurements, was used to assess the capacity of the two former instruments to correctly describe the $\mathrm{PM}_{1}$ fraction over long-term periods. For this purpose, the reconstructed $\mathrm{PM}_{1}\left(\mathrm{PM}_{\mathrm{chem}}\right)$ introduced here corresponds to the sum of all non-refractory species measured by the ACSM (OM, $\mathrm{NO}_{3}^{-}, \mathrm{SO}_{4}^{2-}, \mathrm{NH}_{4}^{+}$and $\left.\mathrm{Cl}^{-}\right)$and black carbon measured by Aethalometer, and is assumed to quasi-exhaustively account for submicron aerosols (Putaud et al., 2004). $\mathrm{PM}_{\text {chem }}$ daily averages were compared to the TEOM-FDMS data set, since the latter instrument is considered to be equivalent to the gravimetric reference method on this temporal scale. From June 2011 to May 2013, the 341point (this number being due to the combined availability of ACSM, BC and PM data) scatterplot shows a very satisfactory correlation coefficient $\left(r^{2}=0.85\right)$ with a slope of 1.06 .

\section{Representativeness of our 2-year observation period}

Monthly mean atmospheric conditions were compared to standard meteorological parameters in order to investigate any anomalies over the 2011-2013 period (Fig. 4). Temperature, rainfall and sun exposure representative of the region of Paris were retrieved from monthly weather reports available at https://donneespubliques.meteofrance.fr, and are calculated from a 30-year period (1981-2010) (Arguez and Vose, 2011). A similar study was also performed for particulate matter concentrations, with representative $\mathrm{PM}_{2.5}$ defined as the average $\mathrm{PM}_{2.5}$ concentrations calculated from 2007 to 2014 at the three historical Airparif urban background stations. 


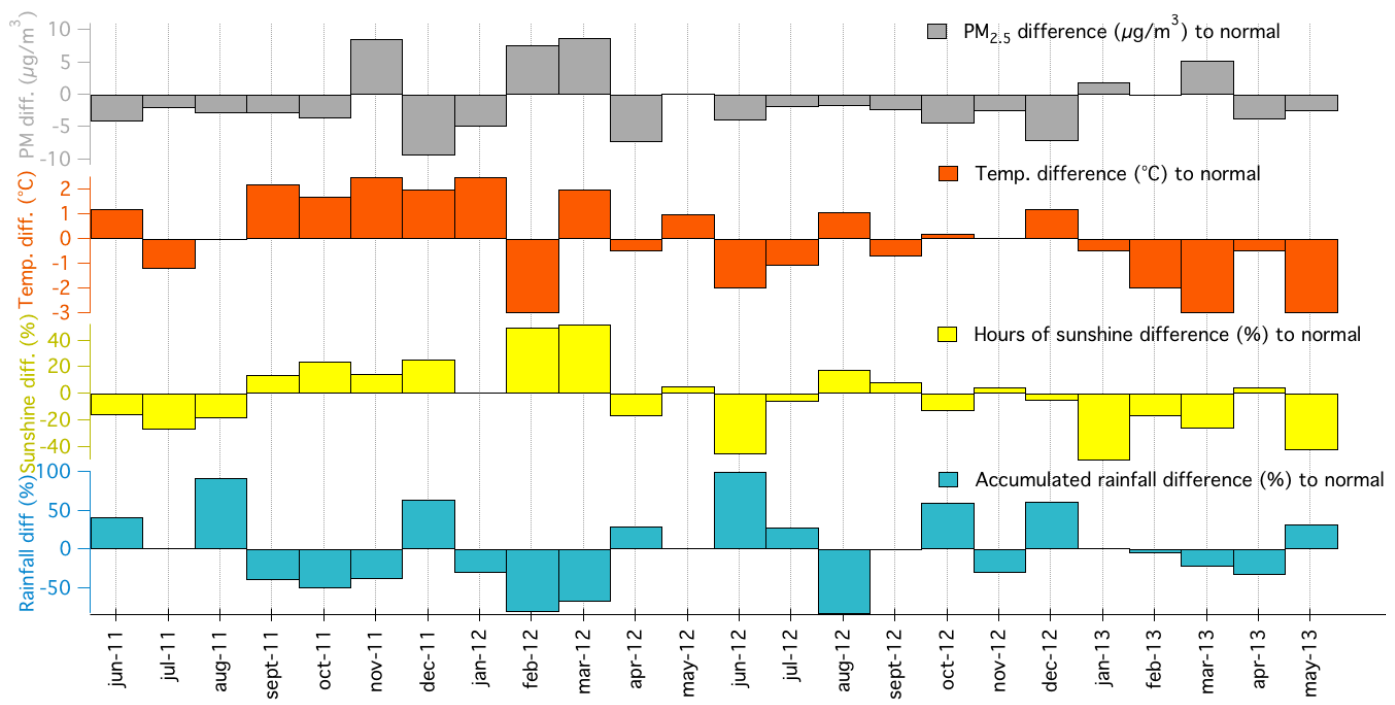

Figure 4. Comparison between observed and average $\mathrm{PM}_{2.5}$, temperature, hours of sunshine and accumulated rainfall in the region of Paris.

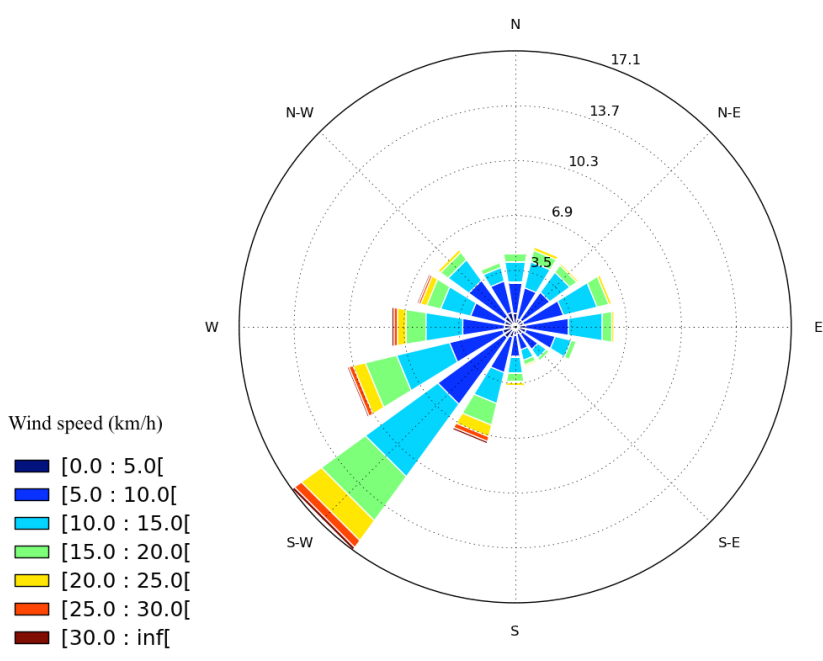

Figure 5. Average wind rose during June 2011 and June 2013; the radial axis represents the wind occurrence (in \%).

Briefly, autumn 2011 was relatively mild, $\mathrm{PM}_{2.5}$ levels being close to representative concentrations for the period. The end of winter 2011-2012 and early spring 2012 were particularly dry and sunny, enabling enhanced photochemical transformation, and exhibited unusually high $\mathrm{PM}_{2.5}$ concentrations in February and March 2012. The summer of 2012 was chilly and rainy, especially in June 2012, leading to lower $\mathrm{PM}_{2.5}$ levels (Yiou and Cattiaux, 2013). Finally, the first two months of 2013 were unusually cold, whereas March 2013 was remarkably representative of wintertime conditions. The highest observed discrepancies occur with the highest measured mass, which may highlight an intensification of pollution episodes. From a broader perspective, this feature is also observed through inter-annual variability of urban background $\mathrm{PM}_{2.5}$ concentrations (Fig. S2). This underlines the need for continuous monitoring over several year periods. Interestingly, no direct link can be drawn between meteorological anomalies and unusually high $\mathrm{PM}_{2.5}$ concentrations. Indeed, while the high $\mathrm{PM}_{2.5}$ levels observed in February and March 2012 may be linked to unusually low temperatures, exceptionally high temperatures can also be associated with high $\mathrm{PM}_{2.5}$ concentrations. This has to be related to the seasonal variability of sources, origins and (trans)formation pathways, and is investigated within the following sections, taking advantage of long-term trend analysis, wind regression, diurnal variations, and the analysis of pollution episodes.

Finally, it should be underlined that the Paris region is mostly influenced by winds coming from the southwestern (Fig. 5) sector. This sector is characterized by clean air masses from the Atlantic Ocean with high wind speeds, and is usually associated with low PM concentrations. The northeastern wind sector exhibits a smaller occurrence than previously observed between September 2009 and September 2010 (Supplementary information of Bressi et al., 2013).

\section{Long-term trend and general features}

Two-year temporal variations of the chemical composition of submicron aerosols $\left(\mathrm{OM}, \mathrm{NO}_{3}^{-}, \mathrm{SO}_{4}^{2-}, \mathrm{NH}_{4}^{+}, \mathrm{Cl}^{-}, \mathrm{BC}_{\mathrm{ff}}\right.$ and $\left.\mathrm{BC}_{\mathrm{wb}}\right)$ and ammonia $\left(\mathrm{NH}_{3}\right)$ are presented in Fig. 1. Similarly to Bressi et al. (2013), a clear seasonal pattern is observed here, with the highest concentrations observed during winter and early spring, while summer periods exhibit the lowest pollution levels (Fig. 6a), which is also consistent with general patterns observed in northern Europe (Barmpadimos et al., 2012; Waked et al., 2014). Regardless of the season, $\mathrm{OM}$ dominates the $\mathrm{PM}_{1}$ chemical composition, followed by ammonium nitrate, whose contribution is highest during 

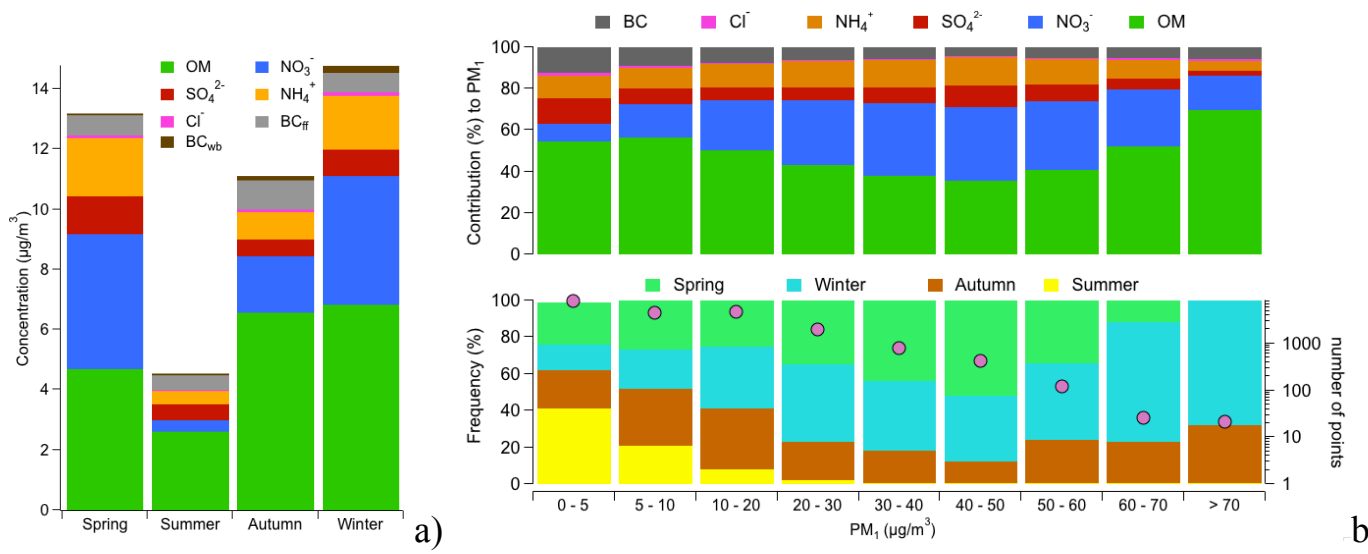

Figure 6. (a) $\mathrm{PM}_{1}$ chemical composition for different mass classes (top), with the seasonal occurrence frequency and number of points in each bin (bottom) and (b) seasonal $\mathrm{PM}_{1}$ chemical composition.

spring, a feature that is generally observed for European urban areas (Zhang et al., 2007; Putaud et al., 2010). Figure 6b presents the binned major chemical composition and the frequency per season of data points as a function of $\mathrm{PM}_{1}$ concentration levels. The contribution of secondary inorganic aerosols (SIA, mostly $\mathrm{NO}_{3}^{-}, \mathrm{SO}_{4}^{2-}$ and $\mathrm{NH}_{4}^{+}$) increases with the increases in $\mathrm{PM}_{1}$ mass until $50 \mu \mathrm{g} \mathrm{m}^{-3}$, highlighting the role of inorganic secondary pollution during spring months (Fig. 6b). This well-documented pattern that has already been reported for the region of Paris in several studies (see, for instance, Sciare et al., 2010 and Bressi et al., 2013). Very interestingly, above $50 \mu \mathrm{g} \mathrm{m}^{-3}$, organic contribution, as well as wintertime frequency, increases to dominate the chemical composition of the highest measured $\mathrm{PM}_{1}$ concentrations with an associated increase in $\mathrm{BC}$, a feature that has not been seen during the Airparif-Particules projects, essentially due to highly time resolved measurements, nor investigated during the MEGAPOLI project. There are well-defined occurrences of high concentrations ( $\sim 150$ data points of $30 \mathrm{~min}$ ), suggesting sharp pollution events with a limited temporal duration, contrary to the $20-50 \mu \mathrm{g} \mathrm{m}^{-3}$ mass class presenting many more data points that highlight either a higher frequency of sharp events and/or pollution episodes with a longer temporal duration.

We have used here the $\mathrm{BC} / \mathrm{SO}_{4}$ ratio to assess potential transport of pollution. Sulfate mainly forms through heterogeneous processes with a slow kinetic rate and spreads over large scales (Putaud et al., 2004). For that reason, it can be considered as a good indicator of long-range transport assuming minor local $\mathrm{SO}_{2}$ sources (background annual $\mathrm{SO}_{2}$ concentrations of about $2 \mu \mathrm{g} \mathrm{m}^{-3}$ in the region of Paris; AIRPARIF, 2014). On the contrary, black carbon in the region of Paris shows an important gradient from the city center to the regional background (Bressi et al., 2013) and can be used to better infer local (Paris city) influence at our background station. Although in situ sulfate formation may occur (for instance, during fog episodes; Healy et al., 2012) and long-range transport of BC may be observed over the region of Paris (Healy et al., 2012 and 2013), as a whole, the use of the $\mathrm{BC} / \mathrm{SO}_{4}$ ratio may support our study on local/regional/advected pollution. As shown in Fig. 7, the $\mathrm{BC} / \mathrm{SO}_{4}$ ratio decreases along with the increase in $\mathrm{PM}_{1}$ (and thus secondary ion mass fraction), suggesting potential regional and/or trans-boundary transport, and large-scale pollution episodes, as previously reported by several studies in northern France (Bessagnet et al., 2005; Sciare et al., 2010; Bressi et al., 2013; Waked et al., 2014; Freutel et al., 2013). Very interestingly, this $\mathrm{BC} / \mathrm{SO}_{4}$ ratio dramatically increases for the highest concentrations, where the concomitant increases in the Ångström exponent, of the contribution of $\mathrm{BC}_{\mathrm{wb}}$ relative to $\mathrm{BC}$, along with the increase in $\mathrm{OM}$ and wintertime frequency (Fig. 7), suggest intense local and/or regional wood-burning pollution episodes during winter. Moreover, except for the single wood-burning episode observed on 5 February 2012 (described in Petit et al., 2014), all these intense PM pollution peaks $\left(\mathrm{PM}_{1}>60 \mu \mathrm{g} \mathrm{m}^{-3}\right)$ also occurred at most of the rural/suburban/urban Airparif monitoring stations. This pattern underlines homogeneous meteorological conditions over the region of Paris, with "local" emissions being measured on a regional scale (within a distance of at least $50 \mathrm{~km}$ from the city center).

\section{Seasonality and insights into geographical origins}

Figure 8 displays the wind regression analysis plots for species of interest, namely, $\mathrm{OM}, \mathrm{NO}_{3}^{-}, \mathrm{SO}_{4}^{2-}, \mathrm{NH}_{3}, \mathrm{BC}_{\mathrm{ff}}$ and $\mathrm{BC}_{\mathrm{wb}}$.

Overall, OM concentrations do not exhibit a particular dependence on wind direction, the regional background always staying at a significant contribution throughout seasons $\left(\sim 3-6 \mu \mathrm{g} \mathrm{m}^{-3}\right)$. However, higher OM concentrations occurred in autumn and winter and are associated with very low wind speeds, suggesting higher local influence together with higher local wood-burning emissions (as previously 


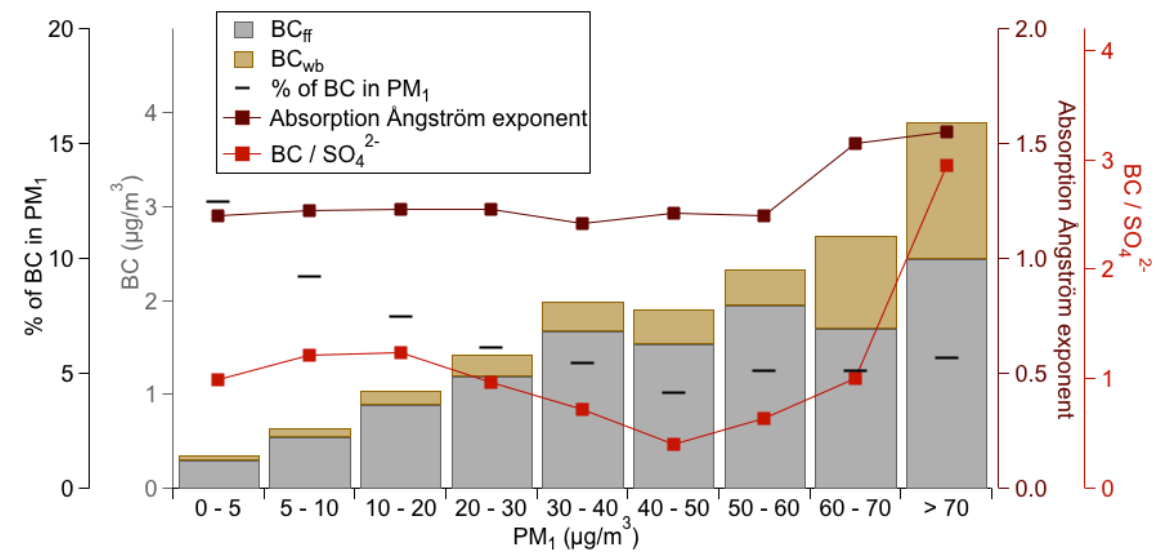

Figure 7. Source contribution to $\mathrm{BC}$, absorption Ångström exponent, $\mathrm{BC} / \mathrm{SO}_{4}$ ratio (ACSM sulfate), and contribution of $\mathrm{BC}$ to $\mathrm{PM}$, depending on $\mathrm{PM}_{1}$ mass.

suggested from Figs. $6 \mathrm{~b}$ and 7$)$. During summer, OM concentrations are lower (by a factor of $\sim 2.2$ ) and show a more homogeneous distribution (e.g., with lower local influences).

As expected, semi-volatile nitrate concentrations are higher during the coldest months (in spring and winter). They are associated with relatively high wind speeds $\left(\sim 20 \mathrm{~km} \mathrm{~h}^{-1}\right)$ coming from the northerly and northeasterly directions, suggesting significant medium- to long-range transport of ammonium nitrate during these seasons, which is consistent with similar observations reported for the region of Paris (Bressi et al., 2013; Freutel et al., 2013; Petetin et al., 2014). However, the significant nitrate concentrations observed for all the range of wind speeds from the N-NE direction suggest, at least for the lowest wind speed, a significant contribution of the region of Paris. Possible impacts of industrial activities in the Seine estuary (i.e., Rouen, Le Havre), especially during spring, may also be responsible for the noticeable nitrate hotspot observed in the northwestern sector. In autumn, nitrate concentrations are higher at low wind speeds, in agreement with the fact that traffic emissions are slightly higher in September and October than the rest of the year in Paris (V-Trafic report, 2014), and that $\mathrm{BC}_{\mathrm{ff}}$ concentrations are also highest during these months. This is also consistent with a relatively fast nitrate formation mechanism from local $\mathrm{NO}_{\mathrm{x}}$ emissions as reported by Petetin et al. (2014).

Sulfate features different behavior than nitrate, where the non-local origin is much more pronounced. High concentrations are associated with high wind speeds originating from the NNE, leading to the same conclusions as those reported in the literature on the major role of the long-range transport of this compound (Pay et al., 2012; Bressi et al., 2014; Petetin et al., 2014; Waked et al., 2014). Petrochemical and shipping activities may explain the observed hotspot in the marine northwestern sector, especially noticeable in spring, which may be linked to meteorological conditions enhancing ammonium sulfate formation and transport.
The region of Brittany, located less than $300 \mathrm{~km}$ west of the region of Paris, is the principal emitter of ammonia in France through intense agricultural activities (http://prtrec. europa.eu/DiffuseSourcesAir.aspx). However, no clear contribution from this region is observed from our wind regression analysis. This may be partly related to very few occurrences of air masses passing over Brittany and reaching the region of Paris. Despite hotspots from the northeast/east in spring, or from the north/northeast in winter, no clear wind sector is directly responsible for high $\mathrm{NH}_{3}$ concentrations at our station, suggesting a diffuse regional source for this compound.

In Europe, $\mathrm{BC}_{\mathrm{ff}}$ is assumed to be an excellent tracer of traffic emissions in urban areas (Herich et al., 2011, for instance). Although long-range transported $\mathrm{BC}_{\mathrm{ff}}$ may not be excluded, as shown by Healy et al. $(2012,2013)$, here, wind regression analyses show that high $\mathrm{BC}_{\mathrm{ff}}$ concentrations occurred at low wind speeds, highlighting the importance of local/regional traffic emissions in the Paris region, especially during the autumn and winter seasons. In spring, a clear distribution over a large range of wind speeds is noticeable in the NNE wind sector. This is consistent with the fact that Paris is located NNE of our station (e.g., a higher contribution of the Paris city plume to measured $\mathrm{BC}_{\mathrm{ff}}$ concentrations at SIRTA). This is also related to a higher occurrence of this wind sector during spring.

Black carbon from biomass burning combustion $\left(\mathrm{BC}_{\mathrm{wb}}\right)$ presents a clear seasonal trend similar to OM, with the highest concentrations during cold seasons at low wind speeds, suggesting increasing local influence in wood-burning emissions. The lowest boundary layer heights (BLHs) observed during wintertime favoring the accumulation of pollutants at ground level together with the large contribution of individual (domestic) wood-burning sources homogeneously spread over the region of Paris may explain the significant contribution of regional emissions observed during winter. 


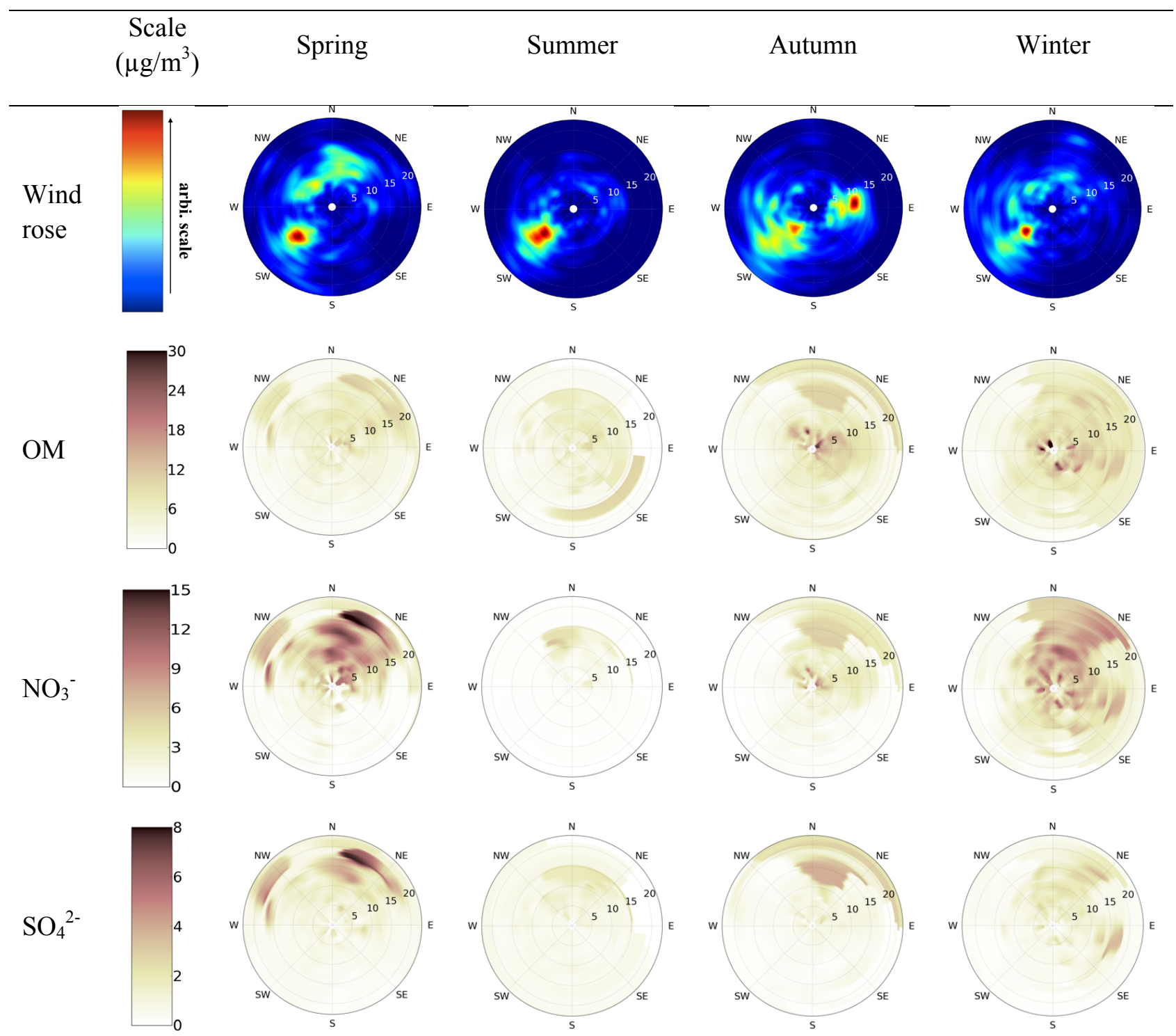

Figure 8.

Finally, it should be noted that the geographical origin of each investigated chemical constituent remains globally unchanged throughout the year, with a well-defined sectorized location. While SIA and $\mathrm{BC}_{\mathrm{ff}}$ fractions are mainly associated with the NNE sector (coming from Paris and/or farther away), the highest $\mathrm{OM}$ and $\mathrm{BC}_{\mathrm{wb}}$ concentrations exhibit strong local NW and SE sector origins. Various sources of organic matter also contribute to a significant contribution of the (unsectorized) regional background.

\section{Weekly diurnal profiles and insight into sources and processes}

Near real-time observations over long-term periods offer a unique opportunity to provide robust diurnal profiles for each season. First, Fig. 9 shows the average diurnal profiles of ambient temperatures (Fig. 9a) and BLH (Fig. 9b) across seasons. Weekly diurnal profiles for $\mathrm{OM}, \mathrm{NO}_{3}^{-}, \mathrm{NH}_{4}^{+}, \mathrm{NH}_{3}$, $\mathrm{BC}_{\mathrm{ff}}$ and $\mathrm{BC}_{\mathrm{wb}}$ are presented for different seasons from hourly averages (Fig. 10). Sulfate variations are not presented and discussed here because they lead to poor daily variations (average of $0.75 \mu \mathrm{g} \mathrm{m}^{-3} \pm 2 \%$ ), which are consistent with its mid- to long-range transport origin.

Clear weekly and diurnal patterns can be observed for carbonaceous aerosols. Independently of the investigated season, $\mathrm{BC}_{\mathrm{ff}}$ presents a well-marked bimodal diurnal profile, with maxima in the morning (starting at 06:00 UTC) and the evening (starting at 17:00). This reflects the proximity of the traffic source (with daily commuting) and dilution in the boundary layer during daytime (Fig. 9b). With an average 

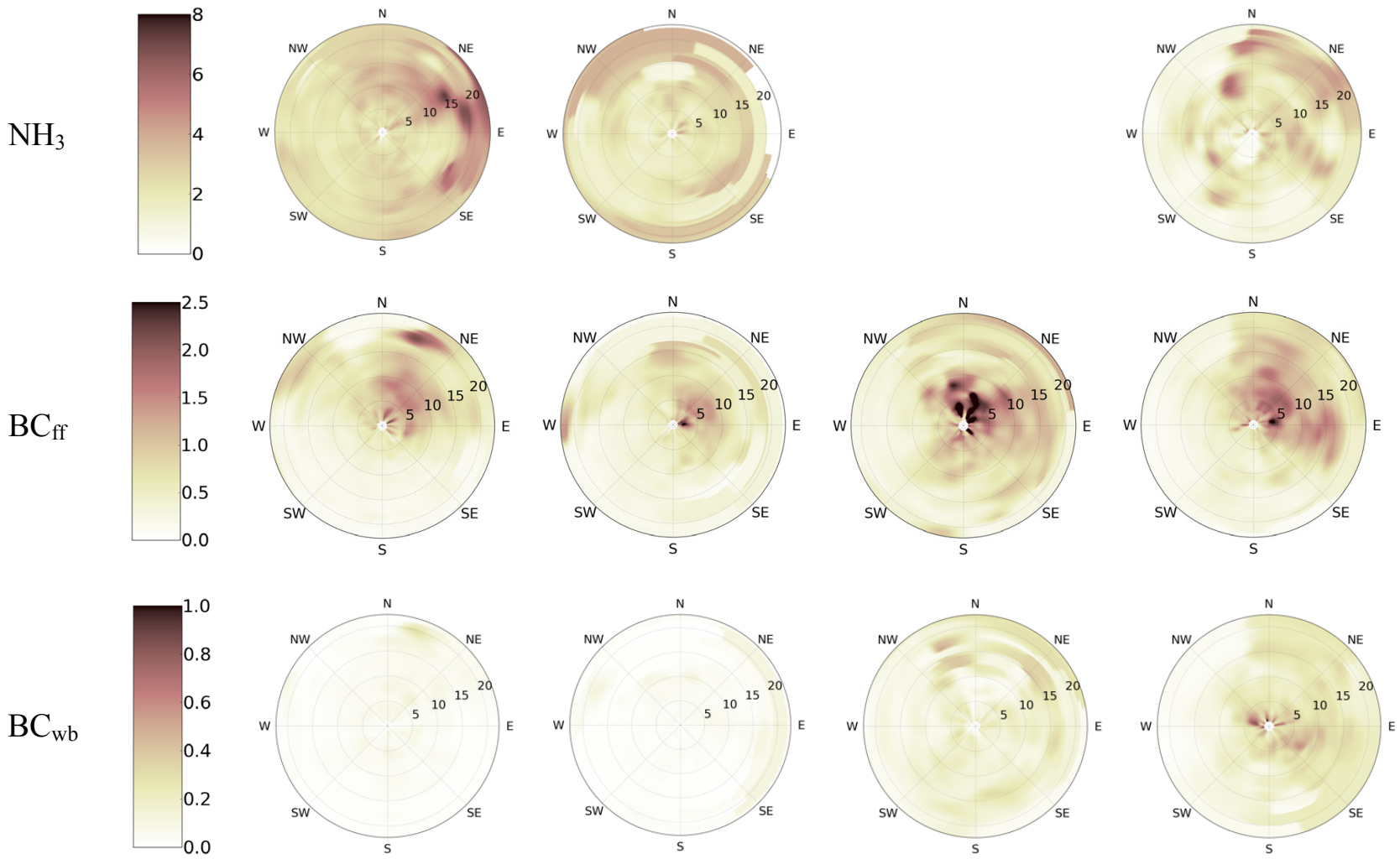

Figure 8. Seasonal NWR plots for the major components of $\mathrm{PM}_{1}$ and gaseous ammonia. Radial and tangential axes represent the wind direction and speed $\left(\mathrm{km} \mathrm{h}^{-1}\right)$, respectively.
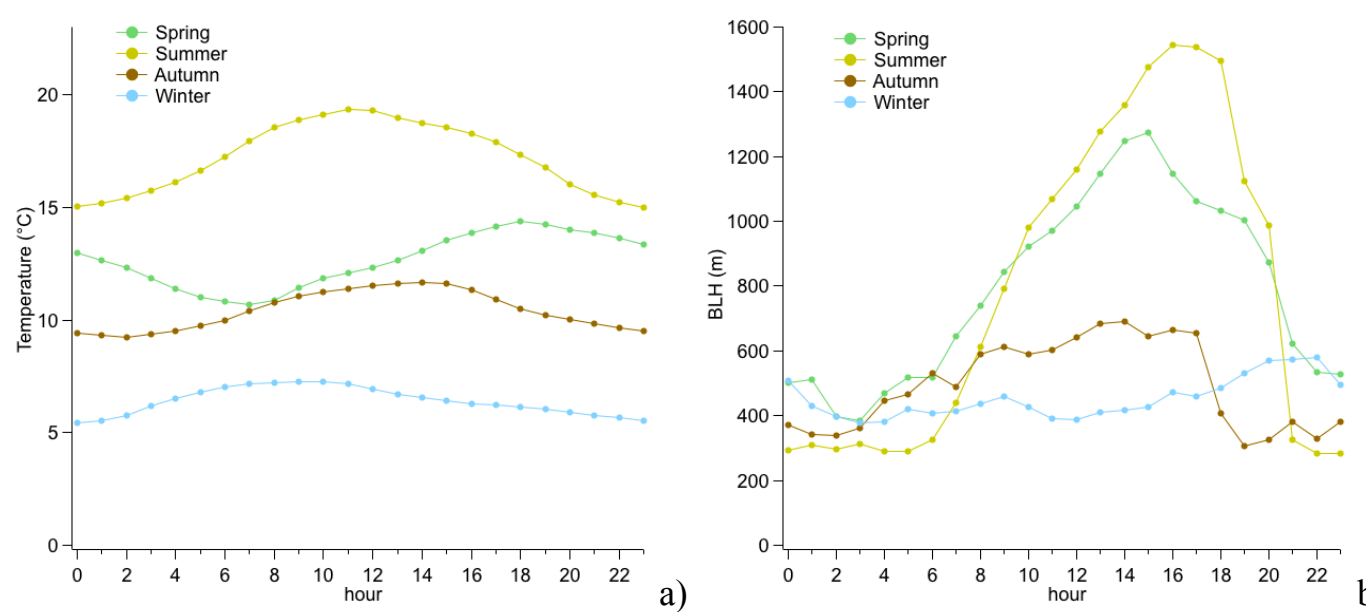

Figure 9. Average diurnal variations by seasons of temperature (a) and BLH (b).

of $0.61 \mu \mathrm{g} \mathrm{m}^{-3}$, weekdays exhibit slightly higher concentrations than weekends $\left(0.51 \mu \mathrm{g} \mathrm{m}^{-3}\right.$ on average $)$. By comparison, the diurnal variability of $\mathrm{BC}_{\mathrm{wb}}$ is revealed only in autumn and winter, with the combination of enhanced woodburning emissions, low temperatures and BLH (Fig. 9), leading to a unimodal pattern with increasing concentrations after 18:00 UTC. Although individual wood-burning stoves only represent around $5 \%$ of the means of heating in the region of
Paris, they contribute almost $90 \%$ of $\mathrm{PM}_{10}$ residential emissions in the region of Paris (Airparif emission inventory for the year 2010; Airparif, 2013) and are likely to represent the major contributor to $\mathrm{BC}_{\mathrm{wb}}$.

For OM, the highest variations (in terms of concentration amplitude) are observed during autumn and winter, with a growing influence of wood-burning heating, as OM concentrations nicely follow $\mathrm{BC}_{\mathrm{wb}}$ ones. Levels of both com- 
Spring
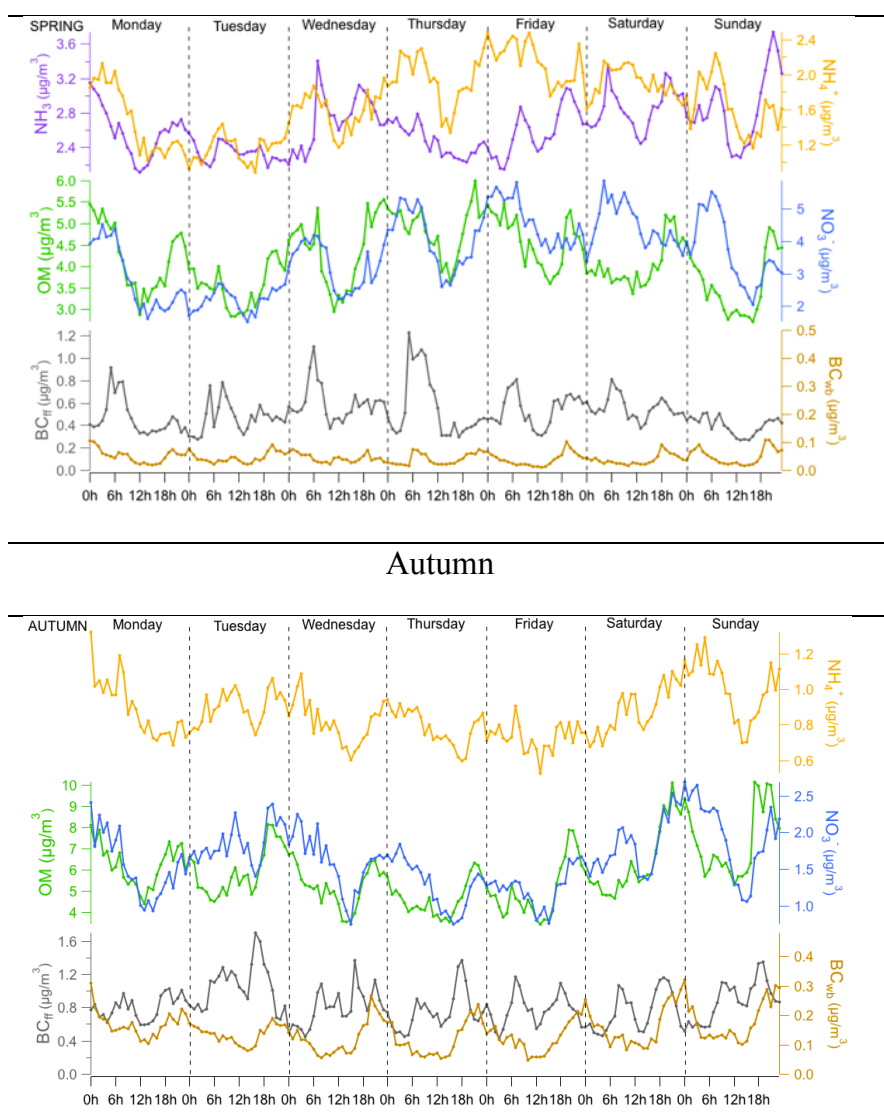

Figure 10. Seasonal weekly diurnal variations of $\mathrm{OM}$ (green), $\mathrm{NO}_{3}^{-}$ (brown).

pounds during the evening are approximately $20 \%$ higher during weekends than during weekdays. More specifically, low BLHs in winter (Fig. 9b) increase measured concentrations, leading, for example, to morning OM peaks that should be linked to traffic emissions. By contrast, the diurnal profile is rather flat, with poor temporal variations in summer, and is in accordance with the homogeneous geographical distribution from the NWR calculation for this season. The lack of a decrease in the afternoon during weekdays suggests rapid formation of secondary organic aerosols (SOA) from diverse anthropogenic (traffic for instance, as underlined by Platt et al., 2013 and Nordin et al., 2013) and biogenic sources (Carlton et al., 2009). During spring, OM globally follows the variations of nitrate, highlighting fast displacements of gasparticle equilibriums of semi-volatile material due to meteorological conditions. Some peaks are observed some days during the night, which could underline the residual contribution of wood-burning emissions in March and April.

For SIA, nitrate and ammonium display very similar diurnal and weekly profiles, illustrating the importance of ammonium nitrate by comparison with ammonium sulfate. Both compounds display well-marked diurnal profiles with max-

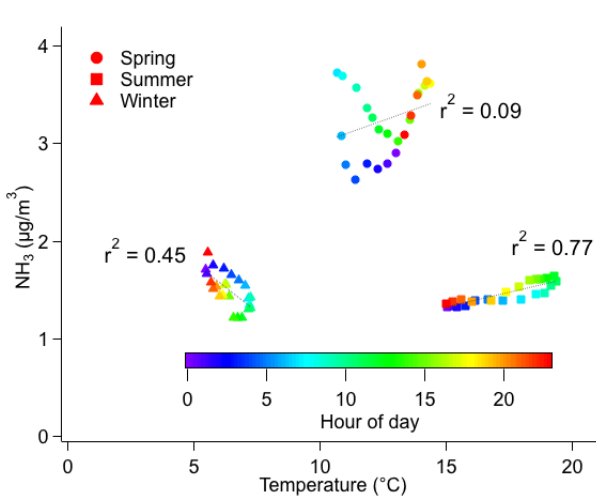

Figure 11. Correlation between ammonia and temperature in spring (circles), summer (squares) and winter (triangles) colored as a function of the hour of the day.

ima at night (especially in autumn and winter) and/or early morning (especially in spring and summer), which has to be related to the enhancement of ammonium nitrate formation at low temperatures and/or high relative humidity. The temporal variations of the two compounds can also be linked to the 
one of ammonia. For instance, during summertime, ammonia presents unimodal diurnal profiles, with the highest values around noon, and nicely follows temperature (Fig. 9a), in good agreement with previous studies (Bari et al., 2003; Lin et al., 2006). This phenomenon is exactly opposite to the variations of ammonium and nitrate exhibiting unimodal patterns with the highest concentrations during the night. Meteorological conditions can then fully explain the formation/partitioning of SIA as well as ammonia concentrations during summer.

Interestingly however, ammonia shows different profiles as a function of the season. In particular, during springtime, this compound displays a clear bimodal profile, with a morning and an evening peak, concomitant with traffic emissions and that come over elevated regional background levels due to the use of nitrogen-containing fertilizers in this period of the year. However, this bimodal pattern is not observed during the summer and winter seasons, where traffic also occurs. Although traffic-related ammonia has already been reported in urban environments (Edgerton et al., 2007; Pandolfi et al., 2012; Saylor et al., 2010) and several studies raise concerns about uncontrolled ammonia emissions from $\mathrm{De}-\mathrm{NO}_{\mathrm{x}}$ systems (Baum et al., 2001; Heeb et al., 2006 and 2012, for instance), this spring bimodal profile may also be related to parameters other than traffic emissions. Indeed, as already described by Bussink et al. (1996), emission of ammonia can occur during the evaporation of the morning dew, especially when soils are loaded with fertilizers. The morning decrease observed for ammonia in spring can then be associated with the growing of the mixing depth layer (Fig. 9b) while, in the afternoon, ammonia increases may be partly explained by temperature-driven gas-phase partitioning changes in ammonium nitrate.

\section{$8 \mathrm{PM}_{1}$ pollution episodes over the region of Paris}

An in-depth characterization of each pollution episode over the region of Paris is particularly important in the context of mitigation policies, which are usually taken on a local scale during these episodes. Such an investigation should provide useful information regarding PM (trans)formation processes and help to identify parameters influencing the temporality of their chemical composition.

Statistical representativeness of pollution episodes (duration and intensity) may be addressed using our long-term data sets. Based on our 2-year data set, the highest $1 \%$ of observed $\mathrm{PM}_{1}$ concentrations $\left(q_{99} \sim 49 \mu \mathrm{g} \mathrm{m}^{-3}\right.$, representing around 200 data points of $30 \mathrm{~min}$, i.e., approximately $100 \mathrm{~h})$ mostly occur during February, April and November, while persistent pollution episodes $\left(\mathrm{PM}_{1}>20 \mu \mathrm{g} \mathrm{m}^{-3}\right.$ during at least 3 consecutive days) mostly occur in early spring. More interestingly, the majority of the highest $\mathrm{PM}_{1}$ concentrations fall within these persistent pollution episodes. As previously suggested from higher $\mathrm{BC} / \mathrm{SO}_{4}$ ratios (Sect. 5 and Fig. 7), the highest $\mathrm{PM}_{1}$ concentration peaks are asso-

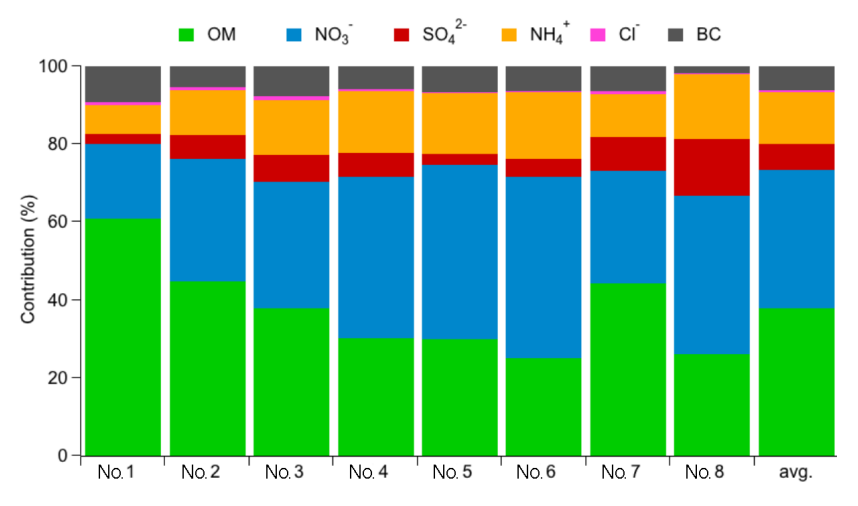

Figure 12. $\mathrm{PM}_{1}$ chemical composition of the eight pollution episodes.

ciated with rather local emissions. This result clearly points to the contribution of local/regional emissions during persistent pollution episodes. A more detailed analysis (episodeby-episode) is performed in the following to better characterize the local/regional versus advected PM pollution during persistent pollution episodes.

Eight persistent pollution episodes $\left(\mathrm{PM}_{1}>20 \mu \mathrm{g} \mathrm{m}^{-3}\right.$ during at least 3 consecutive days) were detected between mid-2011 and mid-2013, and are displayed in Table 2 and Figs. 12 and 13. Figure 12 shows the averaged $\mathrm{PM}_{1}$ chemical composition (in $\mu \mathrm{g} \mathrm{m}^{-3}$ ) for each episode, chronologically numbered, from 1 to 8 . Table 2 summarizes key information for each episode. Figure 13 shows air mass origins, a wind rose and temporal variations of the chemical composition of each episode. As a general pattern for each episode, the chemical composition of $\mathrm{PM}_{1}$ is dominated by $\mathrm{OM}$ and/or ammonium nitrate. Sulfate presents the highest variability (concentration standard deviation of $53 \%$ over all episodes) compared to $\mathrm{OM}$ and nitrate $(\sim 30 \%)$, possibly suggesting various contributions of advected pollution.

The following provides a thorough description of each episode.

Episode 1 (19-24 November 2011): while winds come from the NW and E sectors, $72 \mathrm{~h}$ backtrajectories originate from SSE and exhibit a recirculation over a part of northern France. Moreover, along with the $\mathrm{BC} / \mathrm{SO}_{4}$ ratio (3.56; i.e., the highest of all episodes) and a low BLH with no significant variations, the chemical composition is largely dominated by $\mathrm{OM}\left(60.8 \%\right.$ of $\left.\mathrm{PM}_{1}\right)$, suggesting significant local influence. The contribution of $\mathrm{BC}_{\mathrm{wb}}$ remains insignificant compared to $\mathrm{BC}_{\mathrm{ff}}$, which could underline the accumulation in the atmosphere of fossil-fuelled combustion sources (notably illustrated by the very low altitude of the air masses ending on the 21 and 23 November).

Episode 2 (5-13 February 2012): this episode presents two distinct phases. At the beginning, air masses come from the southeast, but originate from the east at low altitudes, along with very low temperatures (below $0{ }^{\circ} \mathrm{C}$ all day), high $\mathrm{OM}$ and $\mathrm{BC}$ concentrations and $\mathrm{BC} / \mathrm{SO}_{4}$ ratios (average 
Table 2. Essential parameters describing the eight pollution episodes, such as the start and end dates, average temperature and relative humidity, fraction dominating the chemical composition (SIA stands for secondary inorganic aerosols), BC-to-SO $\mathrm{B}_{4}$ ratio and main geographical contribution.

\begin{tabular}{clrrlcl}
\hline Episode no. & Start-end date & Temp. $\left({ }^{\circ} \mathrm{C}\right)$ & $\mathrm{RH}(\%)$ & Chemical composition & $\mathrm{BC} / \mathrm{SO}_{4}$ & Geographical contribution \\
\hline 1 & $19-24 / 11 / 2011$ & 8.5 & 93 & OM & 3.56 & Regional \\
2 & $05-13 / 02 / 2012$ & -4.7 & 71 & OM then SIA & 0.91 & Strong local, then regional and advected \\
3 & $29 / 02-03 / 03 / 2012$ & 8.2 & 95 & SIA & 1.12 & Strong regional, low advected \\
4 & $12-17 / 03 / 2012$ & 10.7 & 78 & SIA & 0.95 & Advected and regional \\
5 & $23-26 / 03 / 2012$ & 15 & 48 & SIA & 2.37 & Strong advected, low regional \\
6 & $28-31 / 03 / 2012$ & 12.3 & 62 & SIA & 1.42 & Strong advected and regional \\
7 & $16-21 / 01 / 2012$ & -3 & 93 & OM and SIA & 0.72 & Strong regional and advected \\
8 & $01-08 / 04 / 2013$ & 4.2 & 64 & SIA & 0.12 & Advected \\
\hline
\end{tabular}

of 22.6 and $0.6 \mu \mathrm{g} \mathrm{m}^{-3}$, and 2.7 , respectively, from 5 to 8 February). This is related to an intense local wood-burning episode already thoroughly described in Petit et al. (2014). Then, from 8 February, winds and air masses originate from NNE, and secondary inorganic ions, especially ammonium nitrate, dominate the chemical composition. The associated wind speed may underline mid- to long-range transport, although the impact of the Paris plume cannot be excluded here.

Episode 3 (29 February-3 March 2012): along with this pollution episode, trajectories have rapidly changed in origin but have remained low in altitude. The RH remained very high, reaching $100 \%$ most of the time. Very interestingly, concentrations dropped on 1 and 3 March during the beginning of the day, coinciding with two stratus lowering fog events. These two fog events occurred during the second half of the night, and evaporated as the sun rose. The influence of fogs regarding the chemical transformation of $\mathrm{PM}_{1}$ is notably highlighted by higher sulfate concentrations just after the evaporation of the first fog (and also when trajectories flew over the English Channel and Belgium), which could suggest transported $\mathrm{SO}_{2}$ and oxidation over the region of Paris enhanced by fast fog processing (Kai et al., 2007; Rengarajan et al., 2011).

Episode 4 (12-17 March 2012): winds have originated from all directions (but mostly from NNE), suggesting anticyclonic conditions. The first half of the period exhibits a rather stable chemical composition (dominated by ammonium nitrate) and clear diurnal variations of RH, $T$ and BHL. Then, after 15 March, daily amplitudes of the following three meteorological parameters increased: $T$ reached $20^{\circ} \mathrm{C}, \mathrm{RH}$ $30 \%$ and BHL $1000 \mathrm{~m}$, compared to the first half, where they reached $15{ }^{\circ} \mathrm{C}, 50 \%$ and $600 \mathrm{~m}$, respectively. This caused rapid decreases in concentrations, due to higher temperature amplitudes, enhancing the gas partitioning of semi-volatile material, and an increase in BLH, allowing the dilution of atmospheric pollutants.

Episode 5 (23 March 2012-26 March 2013): air masses originated from the northeast to the east, and winds from the north to the northeast. This episode is characterized by the strong diurnal variation of $\mathrm{OM}$ and ammonium nitrate, due the high amplitude of the BLH and temperatures going above $15^{\circ} \mathrm{C}$, similarly to the previous episode. The high average $\mathrm{BC} / \mathrm{SO}_{4}$ ratio (2.37) is not representative of its temporality; the highest values are observed for lowest PM concentrations (26 March, afternoon). With this exception, low $\mathrm{BC} / \mathrm{SO}_{4}$ values $(<1)$ and the chemical composition dominated by ammonium nitrate suggest mid- and/or long-range transport.

Episode 6 (28-31 March 2012): it exhibits the same behavior as episode 5, with a clear medium- to long-range origin pattern (wind speed $\sim 10 \mathrm{~km} \mathrm{~h}^{-1}$, chemical composition dominated by ammonium nitrate), but with backtrajectories coming from the northwest/northeast. Low altitudes of backtrajectories illustrate the accumulation of pollutants along the trajectory of the air masses. However, the $\mathrm{BC}$ peak on the morning of 30 March (the high $\mathrm{BC}_{\mathrm{ff}}$ fraction suggests traffic emissions) could underline an influence of the Paris plume.

Episode 7 (16-21 January 2013): air masses display a coiling pattern around northern France. The $\mathrm{BC} / \mathrm{SO}_{4}$ ratio, remaining lower than 1, suggests advected pollution. However, the strong variability of $\mathrm{BC}_{\mathrm{wb}}$ illustrates a significant influence of wood-burning emissions. No BHL data are available during this episode, but the altitude of backtrajectories may underline a more important dilution of the pollution.

Episode 8 (1-8 April 2013): this episode actually started on 22 March, but no ACSM data were available at that time; however, meteorological conditions from 22 March to 1 April were very similar, notably in terms of wind speeds and direction. It is characterized by air masses originating from the northeast and a very low $\mathrm{BC} / \mathrm{SO}_{4}$ ratio, illustrating a typical case of advected secondary pollution clearly dominated by ammonium nitrate and sulfate.

Overall, the observed variability, in terms of meteorological conditions, air mass origins, and chemical composition illustrates the variety of persistent pollution episodes, in terms of PM sources and different geographical origins. The $\mathrm{BC} / \mathrm{SO}_{4}$ ratio has been shown to represent a useful tool for assessing the local/regional/advected dimension of a specific pollution episode. Indeed, high ratios $(\geq 2)$ are usually associated with accumulation of local and/or regional emissions, while very low ratios $(\leq 0.5)$ are more representative 


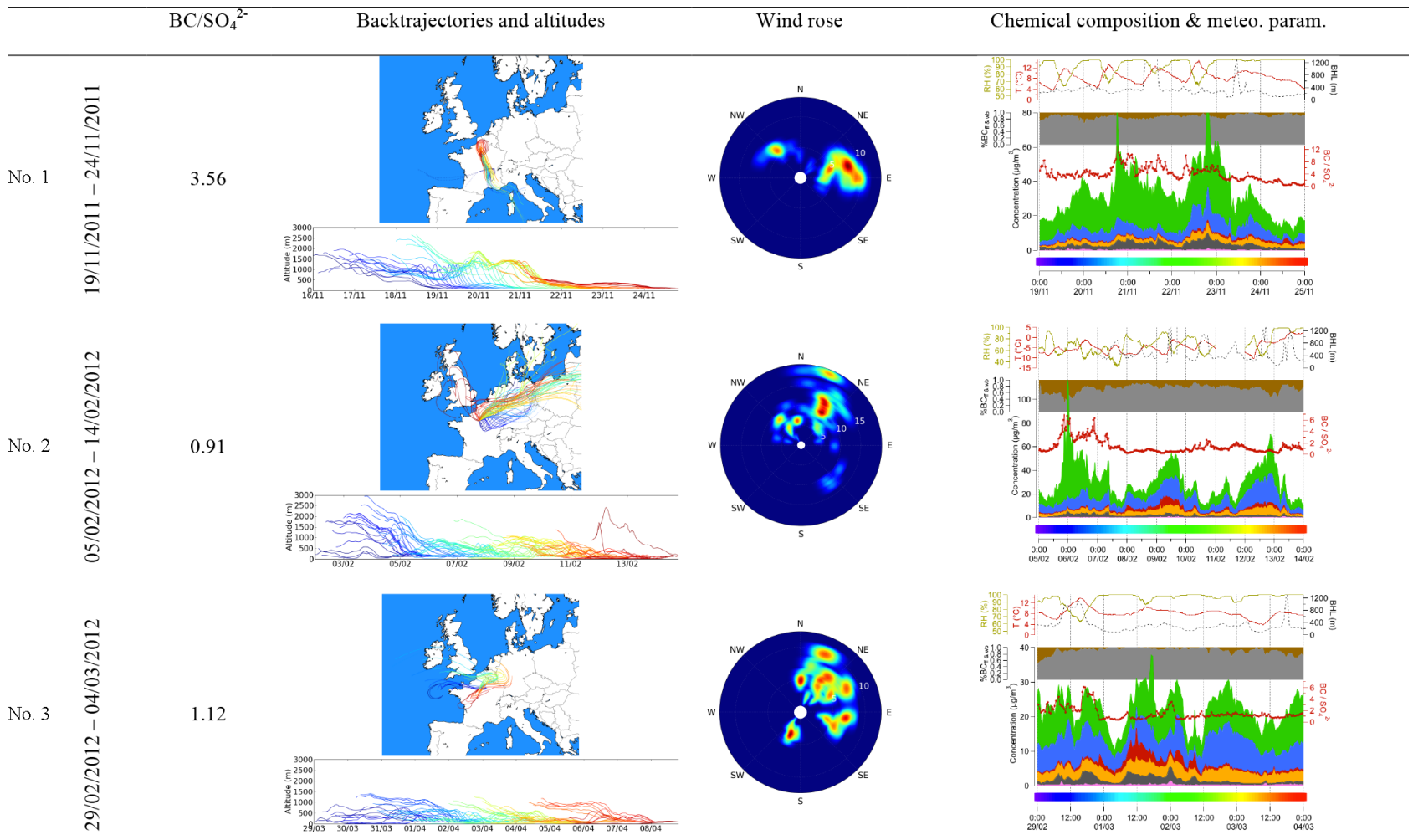

Figure 13.

of secondary advected pollutants. Ratios within this range should then be associated with a combined influence of regional and advected pollution. Finally, artifact-free ACSM data have been shown to be adequate for documenting semivolatile aerosols (ammonium nitrate and a fraction of $\mathrm{OM}$ ), which strongly contribute to $\mathrm{PM}_{1}$ during persistent pollution episodes, and real-time measurements allow one to illustrate the close interactions between the chemical composition and meteorological parameters influencing its temporality.

\section{Conclusions}

The chemical composition of submicron $\left(\mathrm{PM}_{1}\right)$ aerosols was continuously monitored in near real time at a regional background site of the region of Paris between June 2011 and May 2013 using a combination of an ACSM and an Aethalometer. The obtained 2-year data set allows an appraisal of the robustness of ACSM measurements over several month periods, as well as Aethalometer measurements and $\mathrm{BC}$ source apportionment.

Non-parametric wind regression calculations have been performed for each season and provided useful information regarding the geographical origin of $\mathrm{PM}_{1}$ chemical constituents. SIA, in particular ammonium sulfate, show a clear advected pattern, leading to a uniform signal over large scales. Ammonium nitrate also exhibits a significant contribution of regional and local emissions. The highest concen- trations of $\mathrm{OM}$ were identified as having a major local origin, while regional background $\mathrm{OM}$ concentrations remain significant, especially in spring and summer. The region of Brittany (western France), the major hotspot of ammonia in France, seems to have little influence on the concentrations of this species at our station in the region of Paris; overall regional background concentrations of ammonia dominate, especially in spring. Similarly to $\mathrm{OM}$, wintertime $\mathrm{BC}_{\mathrm{wb}}$ concentrations are mainly from local emissions from domestic heating, although a noticeable regional background is still observed for this tracer of wood burning. As expected, $\mathrm{BC}_{\mathrm{ff}}$ shows a clear local (nearby) origin, as well as a contribution from the Paris city plume, and remains fairly constant throughout seasons, due to its regional traffic origin.

Such near real-time observations over long-term periods offer a unique opportunity to provide robust diurnal profiles for each season. For instance, diurnal profiles of semivolatile nitrate aerosols were observed in different seasons with temperatures favoring its partitioning into the particulate phase in the morning and in the gas phase in the afternoon. No clear contribution of traffic could be proven regarding ammonia variability, and the regional background seems to prevail.

All the persistent pollution episodes $\left(\mathrm{PM}_{1}>20 \mu \mathrm{g} \mathrm{m}{ }^{-3}\right.$ during at least 3 consecutive days) that occurred between 2011 and 2013 were carefully examined showing different meteorological conditions, sources and geographical ori- 


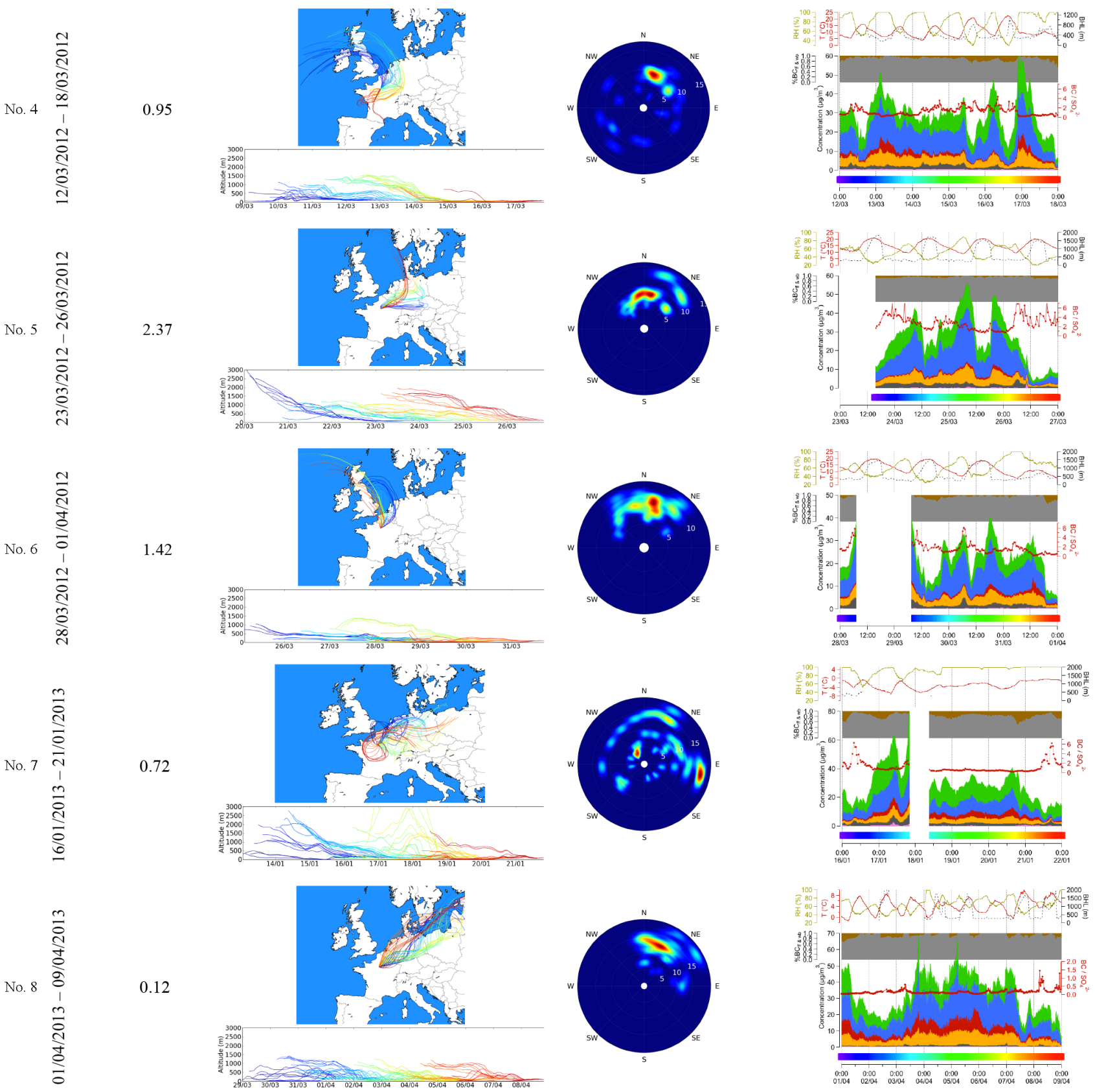

Figure 13. Illustration of meteorological conditions and chemical composition during the eight pollution episodes. Left graphs represent $72 \mathrm{~h}$ backtrajectories ending at SIRTA at $100 \mathrm{~m}$ a.g.l. every $3 \mathrm{~h}$ and their altitude; middle graphs illustrate the wind rose (radial axis in $\mathrm{km} \mathrm{h}^{-1}$ ); right graphs represent the chemical composition, in $\mu \mathrm{g} \mathrm{m}^{-3}$ of submicron particles (organic, nitrate, sulfate, ammonium, chloride and black carbon in green, blue, red, orange, pink and dark grey, respectively), the contribution of traffic and wood burning to $\mathrm{BC}$, the $\mathrm{BC}^{-} \mathrm{SO}_{4}^{2-}$ ratio, and temperature, $\mathrm{RH}$ and $\mathrm{BLH}$.

gins, making it difficult to draw general rules for these episodes. The $\mathrm{BC} / \mathrm{SO}_{4}$ ratio was used here to better separate local, regional (BC dominated) and advected $\left(\mathrm{SO}_{4}\right.$ dominated) contributions, and showed that, with very few exceptions, most of these persistent episodes were dominated by medium- to long-range transported pollution. However, it is interesting to note that the majority of the high- est (time-limited) $\mathrm{PM}_{1}$ concentrations (30 min ACSM data points with $\mathrm{PM}_{1}>50 \mu \mathrm{g} \mathrm{m}^{-3}$ ) fell within these persistent pollution episodes and were characterized by a significant local/regional contribution (high $\mathrm{BC} / \mathrm{SO}_{4}$ ratios). This result, obtained with real-time measurements, may offer new perspectives in the definition and the evaluation of the effectiveness of local mitigation policies such as emergency 
measures (traffic or wood-burning restrictions, for instance) taken to improve air quality during pollution events. In parallel, the long-term characterization of the organic fraction would surely lead to a better assessment of aerosol sources and some (trans)formation processes of secondary pollution in the Ile-de-France area.

In conclusion, these first 2-year quality-controlled measurements of ACSM clearly demonstrate their great potential to monitor on a long-term basis aerosol sources and their geographical origin, and provide strategic information in near real time during pollution episodes. They also support the capacity of the ACSM to be proposed as a robust and credible alternative to filter-based sampling techniques for long-term monitoring strategies. The networking of such instrumentation (ACSM and BC) throughout Europe - as is currently being built up within the European ACTRIS program - will certainly offer tremendous opportunities for modeling studies in order to improve prevision models, as well as largescale spatially and temporally resolved source apportionment studies of organic aerosols using the high potential of ACSM organic fragments.

\section{The Supplement related to this article is available online at doi:10.5194/acp-15-2985-2015-supplement.}

Acknowledgements. The research leading to these results has received funding from INERIS, CNRS, CEA, the French SOEREORAURE network, the European Union Seventh Framework Program (FP7/2007-2013) project ACTRIS under grant agreement no. 262254, the DIM-R2DS program for the funding of the ACSM equipment, and the PRIMEQUAL-PREQUALIF and ADEME-REBECCA programs for the long-term observations of black carbon at SIRTA.

Edited by: J. Allan

\section{References}

Airparif: Bilan des Émissions de Polluants Atmosphériques et de Gaz à Effet de Serre en Île- de-France pour l'Année 2010 et Historique 2000/05: Méthodologie et résultats, available at: http://www.airparif.asso.fr/_pdf/publications/ Emissions_2010_CG75.pdf (last access: February 2015), 2013.

Appel, B. R., Tokiwa, Y., Haik, M., and Kothny, E. L.: Artifact particulate sulphate and nitrate formation on filter media, Atmos. Environ., 18, 409-416, 1984.

Arguez, A. and Vose, R. S.: The Definition of the Standard WMO Climate Normal: The Key to Deriving Alternative Climate Normals, B. Am. Meteorol. Soc., 92, 699-704, doi:10.1175/2010BAMS2955.1, 2011.

Bari, A., Ferraro, V., Wilson, L. R., Luttinger, D., and Husain, L.: Measurements of gaseous $\mathrm{HONO}, \mathrm{HNO}_{3}, \mathrm{SO}_{2}, \mathrm{HCl}, \mathrm{NH}_{3}$, particulate sulphate and $\mathrm{PM}_{2.5}$ in New York, NY, Atmos. Environ., 37, 2825-2835, doi:10.1016/S1352-2310(03)00199-7, 2003.
Barmpadimos, I., Keller, J., Oderbolz, D., Hueglin, C., and Prévôt, A. S. H.: One decade of parallel fine $\left(\mathrm{PM}_{2.5}\right)$ and coarse $\left(\mathrm{PM}_{10}-\mathrm{PM}_{2.5}\right)$ particulate matter measurements in Europe: trends and variability, Atmos. Chem. Phys., 12, 3189-3203, doi:10.5194/acp-12-3189-2012, 2012.

Baum, M. M., Kiyomiya, E. S., Kumar, S., Lappas, A. M., Kapinus, V. A., and Lord, H. C.: Multicomponent remote sensing of vehicle exhaust by dispersive absorption spectroscopy. 2. Direct on-road ammonia measurements, Environ. Sci. Technol., 35, 3735-3741, doi:10.1021/es002046y, 2001.

Bessagnet, B., Hodzic, A., Blanchard, O., Lattuati, M., Lebihan, O., Marfaing, H. and Rouil, L.: Origin of particulate matter pollution episodes in wintertime over the Paris Basin, Atmos. Environ., 39, 6159-6174, doi:10.1016/j.atmosenv.2005.06.053, 2005.

Bond, T. C. and Bergstrom, R. W.: Light Absorption by Carbonaceous Particles: An Investigative Review, Aerosol Sci. Tech., 40, 27-67, doi:10.1080/02786820500421521, 2006.

Bougiatioti, A., Stavroulas, I., Kostenidou, E., Zarmpas, P., Theodosi, C., Kouvarakis, G., Canonaco, F., Prévôt, A. S. H., Nenes, A., Pandis, S. N., and Mihalopoulos, N.: Processing of biomassburning aerosol in the eastern Mediterranean during summertime, Atmos. Chem. Phys., 14, 4793-4807, doi:10.5194/acp-14 4793-2014, 2014.

Bressi, M., Sciare, J., Ghersi, V., Bonnaire, N., Nicolas, J. B., Petit, J.-E., Moukhtar, S., Rosso, A., Mihalopoulos, N., and Féron, A.: A one-year comprehensive chemical characterisation of fine aerosol $\left(\mathrm{PM}_{2.5}\right)$ at urban, suburban and rural background sites in the region of Paris (France), Atmos. Chem. Phys., 13, 78257844, doi:10.5194/acp-13-7825-2013, 2013.

Bressi, M., Sciare, J., Ghersi, V., Mihalopoulos, N., Petit, J.-E., Nicolas, J. B., Moukhtar, S., Rosso, A., Féron, A., Bonnaire, N., Poulakis, E., and Theodosi, C.: Sources and geographical origins of fine aerosols in Paris (France), Atmos. Chem. Phys., 14, 8813-8839, doi:10.5194/acp-14-8813-2014, 2014.

Budisulistiorini, S. H., Canagaratna, M. R., Croteau, P. L., Baumann, K., Edgerton, E. S., Kollman, M. S., Ng, N. L., Verma, V., Shaw, S. L., Knipping, E. M., Worsnop, D. R., Jayne, J. T., Weber, R.J., and Surratt, J. D.: Intercomparison of an Aerosol Chemical Speciation Monitor (ACSM) with ambient fine aerosol measurements in downtown Atlanta, Georgia, Atmos. Meas. Tech., 7, 1929-1941, doi:10.5194/amt-7-1929-2014, 2014.

Bussink, D. W., Harper, L. A., and Corré, W. J.: Ammonia Transport in a Temperate Grassland: II. Diurnal Fluctuations in Response to Weather and Management Conditions, Agron. J., 88, 621-626, 1996.

Cappa, C. D., Onasch, T. B., Massoli, P., Worsnop, D. R., Bates, T. S., Cross, E. S., Davidovits., P., Hakala, J., Hayden, K. L., Jobson, B. T., Kolesar, K. R., Lack, D. A., Lerner, B. M., Li, S.M., Mellon, D., Nuaaman, I., Olfert, J. S., Petaja, T., Quinn, P. K., Song, C., Subramanian, R., Williams, E. J., and Zaveri, R. A.: Radiative absorption enhancements due to the mixing state of atmospheric black carbon, Science, 337, 1078-1081, 2012.

Carbone, S., Saarikoski, S., Frey, A., Reyes, F., Reyes, P., Castillo, M., Gramsch, E., Oyola, P., Jayne, J. T., Worsnop, D. R., and Hillamo, R.: Chemical Characterization of Submicron Aerosol Particles in Santiago de Chile, Aerosol Air Qual. Res., 13, 462473, doi:10.4209/aaqr.2012.10.0261, 2013.

Carlton, A. G., Wiedinmyer, C., and Kroll, J. H.: A review of Secondary Organic Aerosol (SOA) formation from isoprene, At- 
mos. Chem. Phys., 9, 4987-5005, doi:10.5194/acp-9-4987-2009, 2009.

Cavalli, F., Viana, M., Yttri, K. E., Genberg, J., and Putaud, J.-P.: Toward a standardised thermal-optical protocol for measuring atmospheric organic and elemental carbon: the EUSAAR protocol, Atmos. Meas. Tech., 3, 79-89, doi:10.5194/amt-3-79-2010, 2010.

Cheng, Y., He, K. B., Duan, F. K., Zheng, M., Ma, Y. L., and Tan, J. H.: Positive sampling artifact of carbonaceous aerosols and its influence on the thermal-optical split of OC / EC, Atmos. Chem. Phys., 9, 7243-7256, doi:10.5194/acp-9-7243-2009, 2009.

Chow, J. C., Watson, J. G., Mauderly, J. L., Costa, D. L., Wyzga, R. E., Vedal, S., Hidy, G. M., Altshuler, S. L., Marrack, D., Heuss, J. M., Wolff, G. T., Pope, C. A., and Dockery, D. W.: Health Effects of Fine Particulate Air Pollution: Lines that Connect, J. Air Waste Manage., 56, 1368-1380, 2006.

Collaud Coen, M., Weingartner, E., Apituley, A., Ceburnis, D., Fierz-Schmidhauser, R., Flentje, H., Henzing, J. S., Jennings, S. G., Moerman, M., Petzold, A., Schmid, O., and Baltensperger, U.: Minimizing light absorption measurement artifacts of the Aethalometer: evaluation of five correction algorithms, Atmos. Meas. Tech., 3, 457-474, doi:10.5194/amt-3-457-2010, 2010.

Cowen, K., Sumner, A. L., Dinhal, A., Riggs, K., and Willenberg, Z.: Environmental Technology Verification Report, Mechatronics Instruments BV AiRRmonia Ammonia Analyzer, 2004.

Crenn, V., Sciare, J., Croteau, P. L., Favez, O., Verlhac, S., Belis, C. A., Fröhlich, R., Aas, W., Äijälä, M., Alastuey, A., Artiñano, B., Baisnée, D., Baltensperger, U., Bonnaire, N., Bressi, M., Canagaratna, M., Canonaco, F., Carbone, C., Cavalli, F., Coz, E., Cubison, M. J., Gietl, J. K., Green, D. C., Heikkinen, L., Lunder, C., Minguillón, M. C., Močnik, G., O’Dowd, C. D., Ovadnevaite, J., Petit, J.-E., Petralia, E., Poulain, L., Prévôt, A. S. H., Priestman, M., Riffault, V., Ripoll, A., Sarda-Estève, R., Slowik, J., Setyan, A., and Jayne, J. T.: ACTRIS ACSM intercomparison: Part 1 - Intercomparison of concentration and fragment results from 13 individual co-located aerosol chemical speciation monitors (ACSM), Atmos. Meas. Tech. Discuss., submitted, 2015.

Crippa, M., Canonaco, F., Slowik, J. G., El Haddad, I., DeCarlo, P. F., Mohr, C., Heringa, M. F., Chirico, R., Marchand, N., Temime-Roussel, B., Abidi, E., Poulain, L., Wiedensohler, A., Baltensperger, U., and Prévôt, A. S. H.: Primary and secondary organic aerosol origin by combined gas-particle phase source apportionment, Atmos. Chem. Phys., 13, 8411-8426, doi:10.5194/acp-13-8411-2013, 2013a.

Crippa, M., DeCarlo, P. F., Slowik, J. G., Mohr, C., Heringa, M. F., Chirico, R., Poulain, L., Freutel, F., Sciare, J., Cozic, J., Di Marco, C. F., Elsasser, M., Nicolas, J. B., Marchand, N., Abidi, E., Wiedensohler, A., Drewnick, F., Schneider, J., Borrmann, S., Nemitz, E., Zimmermann, R., Jaffrezo, J.-L., Prévôt, A. S. H., and Baltensperger, U.: Wintertime aerosol chemical composition and source apportionment of the organic fraction in the metropolitan area of Paris, Atmos. Chem. Phys., 13, 961-981, doi:10.5194/acp-13-961-2013, 2013b.

Crippa, M., El Haddad, I., Slowik, J. G., DeCarlo, P. F., Mohr, C., Heringa, M. F., Chirico, R., Marchand, N., Sciare, J., Baltensperger, U. and Prevot, A. S. H.: Identification of marine and continental aerosol sources in Paris using high resolution aerosol mass spectrometry, J. Geophys. Res.-Atmos., 118, 1950-1963, doi:10.1002/jgrd.50151, 2013c.
Draxler, R.: Hysplit4 User's Guide, available at: http://www. arl.noaa.gov/documents/reports/hysplit_user_guide.pdf, (last access: 14 May 2014), 1999.

Drinovec, L., Močnik, G., Zotter, P., Prévôt, A. S. H., Ruckstuhl, C., Coz, E., Rupakheti, M., Sciare, J., Müller, T., Wiedensohler, A., and Hansen, A. D. A.: The "dual-spot" Aethalometer: an improved measurement of aerosol black carbon with real-time loading compensation, Atmos. Meas. Tech. Discuss., 7, 1017910220, doi:10.5194/amtd-7-10179-2014, 2014.

Edgerton, E. S., Saylor, R. D., Hartsell, B. E., Jansen, J. J., and Alan Hansen, D.: Ammonia and ammonium measurements from the southeastern United States, Atmos. Environ., 41, 3339-3351, doi:10.1016/j.atmosenv.2006.12.034, 2007.

El Haddad, I., D’ Anna, B., Temime-Roussel, B., Nicolas, M., Boreave, A., Favez, O., Voisin, D., Sciare, J., George, C., Jaffrezo, J.-L., Wortham, H., and Marchand, N.: Towards a better understanding of the origins, chemical composition and aging of oxygenated organic aerosols: case study of a Mediterranean industrialized environment, Marseille, Atmos. Chem. Phys., 13, 78757894, doi:10.5194/acp-13-7875-2013, 2013.

Favez, O., Cachier, H., Sciare, J., Sarda-estève, R., and Martinon, L.: Evidence for a significant contribution of wood burning aerosols to $\mathrm{PM}_{2.5}$ during the winter season in Paris, France, Atmos. Environ., 43, 3640-3644, 2009.

Favez, O., El Haddad, I., Piot, C., Boréave, A., Abidi, E., Marchand, N., Jaffrezo, J.-L., Besombes, J.-L., Personnaz, M.-B., Sciare, J., Wortham, H., George, C., and D'Anna, B.: Inter-comparison of source apportionment models for the estimation of wood burning aerosols during wintertime in an Alpine city (Grenoble, France), Atmos. Chem. Phys., 10, 5295-5314, doi:10.5194/acp-10-52952010, 2010.

Freutel, F., Schneider, J., Drewnick, F., von der Weiden-Reinmüller, S.-L., Crippa, M., Prévôt, A. S. H., Baltensperger, U., Poulain, L., Wiedensohler, A., Sciare, J., Sarda-Estève, R., Burkhart, J. F., Eckhardt, S., Stohl, A., Gros, V., Colomb, A., Michoud, V., Doussin, J. F., Borbon, A., Haeffelin, M., Morille, Y., Beekmann, M., and Borrmann, S.: Aerosol particle measurements at three stationary sites in the megacity of Paris during summer 2009: meteorology and air mass origin dominate aerosol particle composition and size distribution, Atmos. Chem. Phys., 13, 933-959, doi:10.5194/acp-13-933-2013, 2013.

Fröhlich, R., Crenn, V., Setyan, A., Belis, C. A., Canonaco, F., Favez, O., Riffault, V., Slowik, J. G., Aas, W., Aijälä, M., Alastuey, A., Artiñano, B., Bonnaire, N., Bozzetti, C., Bressi, M., Carbone, C., Coz, E., Croteau, P. L., Cubison, M. J., Esser-Gietl, J. K., Green, D. C., Gros, V., Heikkinen, L., Herrmann, H., Jayne, J. T., Lunder, C. R., Minguillón, M. C., Močnik, G., O’Dowd, C. D., Ovadnevaite, J., Petralia, E., Poulain, L., Priestman, M., Ripoll, A., Sarda-Estève, R., Wiedensohler, A., Baltensperger, U., Sciare, J., and Prévôt, A. S. H.: ACTRIS ACSM intercomparison - Part 2: Intercomparison of ME-2 organic source apportionment results from 15 individual, co-located aerosol mass spectrometers, Atmos. Meas. Tech. Discuss., 8, 1559-1613, doi:10.5194/amtd-8-1559-2015, 2015.

Ghersi, V., Rosso, A., Moukhtar, S., Léger, K., Sciare, J., Bressi, M., Nicolas, J., Féron, A., and Bonnaire, N.: Sources of fine aerosol $\left(\mathrm{PM}_{2.5}\right)$ in the region of Paris, Pollution Atmosphérique, Numéro Spécial, Novembre, 2012. 
Grover, B. D.: Measurement of total PM 2.5 mass (nonvolatile plus semivolatile) with the Filter Dynamic Measurement System tapered element oscillating microbalance monitor, J. Geophys. Res., 110, D07S03, doi:10.1029/2004JD004995, 2005.

Haeffelin, M., Barthès, L., Bock, O., Boitel, C., Bony, S., Bouniol, D., Chepfer, H., Chiriaco, M., Cuesta, J., Delanoë, J., Drobinski, P., Dufresne, J.-L., Flamant, C., Grall, M., Hodzic, A., Hourdin, F., Lapouge, F., Lemaître, Y., Mathieu, A., Morille, Y., Naud, C., Noël, V., O'Hirok, W., Pelon, J., Pietras, C., Protat, A., Romand, B., Scialom, G., and Vautard, R.: SIRTA, a ground-based atmospheric observatory for cloud and aerosol research, Ann. Geophys., 23, 253-275, doi:10.5194/angeo-23-253-2005, 2005.

Healy, R. M., Sciare, J., Poulain, L., Kamili, K., Merkel, M., Müller, T., Wiedensohler, A., Eckhardt, S., Stohl, A., Sarda-Estève, R., McGillicuddy, E., O'Connor, I. P., Sodeau, J. R., and Wenger, J. C.: Sources and mixing state of size-resolved elemental carbon particles in a European megacity: Paris, Atmos. Chem. Phys., 12, 1681-1700, doi:10.5194/acp-12-1681-2012, 2012.

Healy, R. M., Sciare, J., Poulain, L., Crippa, M., Wiedensohler, A., Prévôt, A. S. H., Baltensperger, U., Sarda-Estève, R., McGuire, M. L., Jeong, C.-H., McGillicuddy, E., O'Connor, I. P., Sodeau, J. R., Evans, G. J., and Wenger, J. C.: Quantitative determination of carbonaceous particle mixing state in Paris using single-particle mass spectrometer and aerosol mass spectrometer measurements, Atmos. Chem. Phys., 13, 9479-9496, doi:10.5194/acp13-9479-2013, 2013.

Herich, H., Hueglin, C., and Buchmann, B.: A 2.5 year's source apportionment study of black carbon from wood burning and fossil fuel combustion at urban and rural sites in Switzerland, Atmos. Meas. Tech., 4, 1409-1420, doi:10.5194/amt-4-1409-2011, 2011.

Henry, R., Norris, G. A., Vedantham, R., and Turner, J. R.: Source Region Identification Using Kernel Smoothing, Environ. Sci. Technol., 43, 4090-4097, doi:10.1021/es8011723, 2009.

IARC: Outdoor air pollution a leading environmental cause of cancer deaths, press release no. 221, 2013.

Janssen, N. A., Hoek, G., Simic-Lawson, M., Fischer, P., van Bree, L., ten Brink, H., Keuken, M., Atkinson, R. W., Anderson, H. R., Brunekreef, B., and Cassee, F. R.: Black carbon as an additional indicator of the adverse health effects of airborne particles compared with $\mathrm{PM}_{10}$ and $\mathrm{PM}_{2.5}$., Environ. Health Persp., 119, 1691-1699, 2011.

Jayne, J. T., Leard, D. C., Zhang, X., Davidovits, P., Smith, K. S., Kolb, C. E., and Worsnop, D. R.: Development of an Aerosol Mass Spectrometer for Size and Composition Analysis of Submicron Particles, Aerosol Sci. Tech., 33, 49-70, 2000.

Jimenez, J. L., Canagaratna, M. R., Donahue, N. M., Prevot, A. S. H., Zhang, Q., Kroll, J. H., DeCarlo, P. F., Allan, J. D., Coe, H., Ng, N. L., Aiken, A. C., Docherty, K. S., Ulbrich, I. M., Grieshop, A. P., Robinson, A. L., Duplissy, J., Smith, J. D., Wilson, K. R., Lanz, V. A., Hueglin, C., Sun, Y. L., Tian, J., Laaksonen, A., Raatikainen, T., Rautiainen, J., Vaattovaara, P., Ehn, M., Kulmala, M., Tomlinson, J. M., Collins, D. R., Cubison, M. J., Dunlea, E. J., Huffman, J. A., Onasch, T. B., Alfarra, M. R., Williams, P. I., Bower, K., Kondo, Y., Schneider, J., Drewnick, F., Borrmann, S., Weimer, S., Demerjian, K., Salcedo, D., Cottrell, L., Griffin, R., Takami, A., Miyoshi, T., Hatakeyama, S., Shimono, A., Sun, J. Y., Zhang, Y. M., Dzepina, K., Kimmel, J. R., Sueper, D., Jayne, J. T., Herndon, S. C., Trimborn, A.
M., Williams, L. R., Wood, E. C., Middlebrook, A. M., Kolb, C. E., Baltensperger, U., and Worsnop, D. R.: Evolution of Organic Aerosols in the Atmosphere, Science, 326, 1525-1529, doi:10.1126/science.1180353, 2009.

Kai, Z., Yuesi, W., Tianxue, W., Yousef, M., and Frank, M.: Properties of nitrate, sulphate and ammonium in typical polluted atmospheric aerosols $\left(\mathrm{PM}_{10}\right)$ in Beijing, Atmos. Res., 84, 67-77, doi:10.1016/j.atmosres.2006.05.004, 2007.

Laborde, M., Crippa, M., Tritscher, T., Jurányi, Z., Decarlo, P. F., Temime-Roussel, B., Marchand, N., Eckhardt, S., Stohl, A., Baltensperger, U., Prévôt, A. S. H., Weingartner, E., and Gysel, M.: Black carbon physical properties and mixing state in the European megacity Paris, Atmos. Chem. Phys., 13, 5831-5856, doi:10.5194/acp-13-5831-2013, 2013.

Lack, D. A., Cappa, C. D., Covert, D. S., Baynard, T., Massoli, P., Sierau, B., Bates, T. S., Quinn, P. K., Lovejoy, E. R., and Ravishankara, A. R.: Bias in Filter-Based Aerosol Light Absorption Measurements Due to Organic Aerosol Loading: Evidence from Ambient Measurements, Aerosol Sci. Tech., 42, 1033-1041, doi:10.1080/02786820802389277, 2008.

Lanz, V. A., Alfarra, M. R., Baltensperger, U., Buchmann, B., Hueglin, C., and Prévôt, A. S. H.: Source apportionment of submicron organic aerosols at an urban site by factor analytical modelling of aerosol mass spectra, Atmos. Chem. Phys., 7, 15031522, doi:10.5194/acp-7-1503-2007, 2007.

Lin, Y., Cheng, M., Ting, W., and Yeh, C.: Characteristics of gaseous $\mathrm{HNO}_{2}, \mathrm{HNO}_{3}, \mathrm{NH}_{3}$ and particulate ammonium nitrate in an urban city of Central Taiwan, Atmos. Environ., 40, 47254733, doi:10.1016/j.atmosenv.2006.04.037, 2006.

Liousse, C., Cachier, H., and Jennings, S. G.: Optical and thermal measurements of black carbon aerosol content in different environments: variation of the specific attenuation cross-section, sigma, Atmos. Environ., 27A, 1203-1211, 1993.

Middlebrook, A. M., Bahreini, R., Jimenez, J. L., and Canagaratna, M. R.: Evaluation of Composition-Dependent Collection Efficiencies for the Aerodyne Aerosol Mass Spectrometer using Field Data, Aerosol Sci. Tech., 46, 258-271, doi:10.1080/02786826.2011.620041, 2012.

Ng, N. L., Herndon, S. C., Trimborn, A., Canagaratna, M. R., Croteau, P. L., Onasch, T. B., Sueper, D., Worsnop, D. R., Zhang, Q., and Sun, Y. L.: An aerosol chemical speciation monitor (ACSM) for routine monitoring of the composition and mass concentrations of ambient aerosol, Aerosol Sci. Tech., 45, 780794, 2011.

Nordin, E. Z., Eriksson, A. C., Roldin, P., Nilsson, P. T., Carlsson, J. E., Kajos, M. K., Hellén, H., Wittbom, C., Rissler, J., Löndahl, J., Swietlicki, E., Svenningsson, B., Bohgard, M., Kulmala, M., Hallquist, M., and Pagels, J. H.: Secondary organic aerosol formation from idling gasoline passenger vehicle emissions investigated in a smog chamber, Atmos. Chem. Phys., 13, 6101-6116, doi:10.5194/acp-13-6101-2013, 2013.

Olson, D. A., Vedantham, R., Norris, G. A., Brown, S. G., and Roberts, P.: Determining source impacts near roadways using wind regression and organic source markers, Atmos. Environ., 47, 261-268, doi:10.1016/j.atmosenv.2011.11.003, 2012.

Pal, S., Haeffelin, M., and Batchvarova, E.: Exploring a geophysical process-based attribution technique for the determination of the atmospheric boundary layer depth using aerosol lidar and near-surface meteorological measurements: NEW ATTRI- 
BUTION LIDAR-DERIVED ABL DEPTH, J. Geophys. Res.Atmos., 118, 9277-9295, doi:10.1002/jgrd.50710, 2013.

Pancras, J. P., Vedantham, R., Landis, M. S., Norris, G. A., and Ondov, J. M.: Application of EPA Unmix and Nonparametric Wind Regression on High Time Resolution Trace Elements and Speciated Mercury in Tampa, Florida Aerosol, Environ. Sci. Technol., 45, 3511-3518, doi:10.1021/es103400h, 2011.

Pandolfi, M., Amato, F., Reche, C., Alastuey, A., Otjes, R. P., Blom, M. J., and Querol, X.: Summer ammonia measurements in a densely populated Mediterranean city, Atmos. Chem. Phys., 12, 7557-7575, doi:10.5194/acp-12-7557-2012, 2012.

Pay, M. T., Jiménez-Guerrero, P., and Baldasano, J. M.: Assessing sensitivity regimes of secondary inorganic aerosol formation in Europe with the CALIOPE-EU modeling system, Atmos. Environ., 51, 146-164, doi:10.1016/j.atmosenv.2012.01.027, 2012.

Pathak, R., Yao, X., and Chan, C.: Sampling artifacts of acidity and ionic species in $\mathrm{PM}_{2.5}$, Environ. Sci. Technol., 38, 254-259, doi:10.1021/es0342244, 2004.

Petetin, H., Beekmann, M., Sciare, J., Bressi, M., Rosso, A., Sanchez, O., and Ghersi, V.: A novel model evaluation approach focusing on local and advected contributions to urban $\mathrm{PM}_{2.5}$ levels - application to Paris, France, Geosci. Model Dev., 7, 1483 1505, doi:10.5194/gmd-7-1483-2014, 2014.

Petit, J.-E., Favez, O., Sciare, J., Canonaco, F., Croteau, P., Močnik, G., Jayne, J., Worsnop, D., and Leoz-Garziandia, E.: Submicron aerosol source apportionment of wintertime pollution in Paris, France by double positive matrix factorization $\left(\mathrm{PMF}^{2}\right)$ using an aerosol chemical speciation monitor (ACSM) and a multiwavelength Aethalometer, Atmos. Chem. Phys., 14, 1377313787, doi:10.5194/acp-14-13773-2014, 2014.

Platt, S. M., El Haddad, I., Zardini, A. A., Clairotte, M., Astorga, C., Wolf, R., Slowik, J. G., Temime-Roussel, B., Marchand, N., Ježek, I., Drinovec, L., Močnik, G., Möhler, O., Richter, R., Barmet, P., Bianchi, F., Baltensperger, U., and Prévôt, A. S. H.: Secondary organic aerosol formation from gasoline vehicle emissions in a new mobile environmental reaction chamber, Atmos. Chem. Phys., 13, 9141-9158, doi:10.5194/acp-13-91412013, 2013.

Pope, C. A. and Dockery, D. W.: Health Effects of Fine Particulate Air Pollution: Lines that Connect, J. Air Waste Manage., 56, 709-742, doi:10.1080/10473289.2006.10464485, 2006.

Putaud, J.-P., Raes, F., Van Dingenen, R., Brüggemann, E., Facchini, M.-C., Decesari, S., Fuzzi, S., Gehrig, R., Hüglin, C., Laj, P., Lorbeer, G., Maenhaut, W., Mihalopoulos, N., Müller, K., Querol, X., Rodriguez, S., Schneider, J., Spindler, G., Brink, H. ten, Tørseth, K., and Wiedensohler, A.: A European aerosol phenomenology - 2: chemical characteristics of particulate matter at kerbside, urban, rural and background sites in Europe, Atmos. Environ., 38, 2579-2595, doi:10.1016/j.atmosenv.2004.01.041, 2004

Putaud, J.-P., Dingenen, R. V., Alastuey, A., Bauer, H., Birmili, W., Cyrys, J., Flentje, H., Fuzzi, S., Gehrig, R., Hansson, H., Harrison, R., Herrmann, H., Hitzenberger, R., Hüglin, C., Jones, A., Kasper-Giebl, A., Kiss, G., Kousa, A., Kuhlbusch, T., Löschau, G., Maenhaut, W., Molnar, A., Moreno, T., Pekkanen, J., Perrino, C., Pitz, M., Puxbaum, H., Querol, X., Rodriguez, S., Salma, I., Schwarz, J., Smolik, J., Schneider, J., Spindler, G., ten Brink, H., Tursic, J., Viana, M., Wiedensohler, A., and Raes, F.: A European aerosol phenomenology - 3: Physical and chemical characteristics of particulate matter from 60 rural, urban, and kerbside sites across Europe, Atmos. Environ., 44, 1308-1320, doi:10.1016/j.atmosenv.2009.12.011, 2010.

Ramgolam, K., Favez, O., Cachier, H., Gaudichet, A., Marano, F., Martinon, L., and Baeza-Squiban, A.: Size-partitioning of an urban aerosol to identify particle determinants involved in the proinflammatory response induced in airway epithelial cells, Part. Fibre Toxicol., 6, doi:10.1186/1743-8977-6-10, 2009.

Rengarajan, R., Sudheer, A. K., and Sarin, M. M.: Wintertime $\mathrm{PM}_{2.5}$ and $\mathrm{PM}_{10}$ carbonaceous and inorganic constituents from urban site in western India, Atmos. Res., 102, 420-431, doi:10.1016/j.atmosres.2011.09.005, 2011.

Sandradewi, J., Prévôt, A. S. H., Szidat, S., Perron, N., Alfarra, M. R., Lanz, V. A., Weingartner, E., and Baltensperger, U.: Using Aerosol Light Absorption Measurements for the Quantitative Determination of Wood Burning and Traffic Emission Contributions to Particulate Matter, Environ. Sci. Technol., 42, 33163323, doi:10.1021/es702253m, 2008.

Saylor, R. D., Edgerton, E. S., Hartsell, B. E., Baumann, K., and Hansen, D. A.: Continuous gaseous and total ammonia measurements from the southeastern aerosol research and characterization (SEARCH) study, Atmos. Environ., 44, 4994-5004, doi:10.1016/j.atmosenv.2010.07.055, 2010.

Sciare, J., Sarda-estève, R., Favez, O., Cachier, H., Aymoz, G., and Laj, P.: Nighttime residential wood burning evidenced from an indirect method for estimating real-time concentration of particulate organic matter (POM), Atmos. Environ., 42, 2158-2172, 2008.

Sciare, J., d'Argouges, O., Zhang, Q. J., Sarda-Estève, R., Gaimoz, C., Gros, V., Beekmann, M., and Sanchez, O.: Comparison between simulated and observed chemical composition of fine aerosols in Paris (France) during springtime: contribution of regional versus continental emissions, Atmos. Chem. Phys., 10, 11987-12004, doi:10.5194/acp-10-11987-2010, 2010.

Sciare, J., d' Argouges, O., Sarda-Estève, R., Gaimoz, C., Dolgorouky, C., Bonnaire, N., Favez, O., Bonsang, B., and Gros, V.: Large contribution of water-insoluble secondary organic aerosols in the region of Paris (France) during wintertime, J. Geophys. Res.-Atmos., 116, D22203, doi:10.1029/2011JD015756, 2011.

Takegawa, N., Miyazaki, Y., Kondo, Y., Komazaki, Y., Miyakawa, T., Jimenez, J. L., Jayne, J. T., Worsnop, D. R., Allan, J. D., and Weber, R. J.: Characterization of an Aerodyne Aerosol Mass Spectrometer (AMS): Intercomparison with Other Aerosol Instruments, Aerosol Sci. Tech., 39, 760-770, doi:10.1080/02786820500243404, 2005.

Turpin, B. J., Huntzicker, J. J., and Hering, S. V.: Investigation of organic aerosol sampling artifacts in the Los Angeles Basin, Atmos. Environ., 28, 3061-3071, 1994.

Waked, A., Favez, O., Alleman, L. Y., Piot, C., Petit, J.-E., Delaunay, T., Verlinden, E., Golly, B., Besombes, J.-L., Jaffrezo, J.L., and Leoz-Garziandia, E.: Source apportionment of $\mathrm{PM}_{10}$ in a north-western Europe regional urban background site (Lens, France) using positive matrix factorization and including primary biogenic emissions, Atmos. Chem. Phys., 14, 3325-3346, doi:10.5194/acp-14-3325-2014, 2014.

Weingartner, E., Saathoff, H., Schnaiter, M., Streit, N., Bitnar, B., and Baltensperger, U.: Absorption of light by soot particles: determination of the absorption coefficient by means of aethalometers, J. Aerosol Sci., 34, 1445-1463, 2003. 
Yiou, P. and Cattiaux, J.: Contribution of atmospheric circulation to wet north European summer precipitation of 2012, Bull. Amer. Meteorol. Soc., 94, 9, 2013.

Yu, K., Cheung, Y., Cheung, T., and Henry, R. C.: Identifying the impact of large urban airports on local air quality by nonparametric regression, Atmos. Environ., 38, 4501-4507, doi:10.1016/j.atmosenv.2004.05.034, 2004.

Zechmeister-Boltenstern, S.: Training on $\mathrm{NH}_{3}$ measurement by wet chemistry techniques, ACTRIS TNA Activity Report, 2010.

Zhang, Q., Stanier, C. O., Canagaratna, M. R., Jayne, J. T., Worsnop, D. R., Pandis, S. N., and Jimenez, J. L.: Insights into the Chemistry of New Particle Formation and Growth Events in Pittsburgh Based on Aerosol Mass Spectrometry, Environ. Sci. Technol., 38, 4797-4809, doi:10.1021/es035417u, 2004.
Zhang, Q., Jimenez, J. L., Canagaratna, M. R., Allan, J. D., Coe, H., Ulbrich, I., Alfarra, M. R., Takami, A., Middlebrook, A. M., Sun, Y. L., Dzepina, K., Dunlea, E., Docherty, K., DeCarlo, P. F., Salcedo, D., Onasch, T., Jayne, J. T., Miyoshi, T., Shimono, A., Hatakeyama, S., Takegawa, N., Kondo, Y., Schneider, J., Drewnick, F., Borrmann, S., Weimer, S., Demerjian, K., Williams, P., Bower, K., Bahreini, R., Cottrell, L., Griffin, R. J., Rautiainen, J., Sun, J. Y., Zhang, Y. M., and Worsnop, D. R.: Ubiquity and dominance of oxygenated species in organic aerosols in anthropogenically-influenced Northern Hemisphere midlatitudes, Geophys. Res. Lett., 34, L13801, doi:10.1029/2007GL029979, 2007.

Zhang, Q. J., Beekmann, M., Drewnick, F., Freutel, F., Schneider, J., Crippa, M., Prevot, A. S. H., Baltensperger, U., Poulain, L., Wiedensohler, A., Sciare, J., Gros, V., Borbon, A., Colomb, A., Michoud, V., Doussin, J.-F., Denier van der Gon, H. A. C., Haeffelin, M., Dupont, J.-C., Siour, G., Petetin, H., Bessagnet, B., Pandis, S. N., Hodzic, A., Sanchez, O., Honoré, C., and Perrussel, O.: Formation of organic aerosol in the Paris region during the MEGAPOLI summer campaign: evaluation of the volatilitybasis-set approach within the CHIMERE model, Atmos. Chem. Phys., 13, 5767-5790, doi:10.5194/acp-13-5767-2013, 2013. 